KULTURA

i

ILONA SZYMAŃSKA

Warszawa

\title{
TELEFON KOMÓRKOWY - NARZĘDZIE KOMUNIKACJI, NARZĘDZIE ZMIANY SPOŁECZNEJ
}

Komunikacja jest ośrodkiem wszelkiej ludzkiej aktywności, ponieważ wszelka działalność ludzka wymaga koordynacji. Wynalezienie pisma, druku, telegrafu i telefonu, internetu, a w końcu telefonii komórkowej służyło usprawnieniu komunikacji. Jednocześnie wprowadzenie do użycia każdego z tych wynalazków nie tylko w sposób istotny wpłynęło na sposób porozumiewania się, ale także pociągnęło za sobą zmiany organizacyjne w społeczeństwie oraz generowało nowe normy postępowania jednostki. Jak zauważył Neil Postman (2004, s. 31): „Nowa technologia nic nie dodaje, ani niczego nie odejmuje. Nowa technologia wszystko zmienia".

Proces ten nie jest jednak jednokierunkowy. Oczywiście wdrożenie nowych narzędzi komunikacji, podobnie jak wprowadzenie każdego $z$ wynalazków, samo $\mathrm{w}$ sobie nie jest generatorem zmian. Każde $z$ wynalezionych narzędzi (dotyczy to wszelkich nowych technologii) ma niewielki wpływ na życie społeczne dopóty, dopóki nie zostanie znalezione dla niego efektywne zastosowanie, o czym mówi historia wielu wynalazków (Levison 2006a, s. 57). To, jaką rolę odegra innowacja, zależy od sposobu wcielenia jej w nawyki jednostek, a proces ten odbywa się na poziomie społecznym, w toku socjalizacji, a więc zanim dana innowacja się rozprzestrzeni, musi znaleźć społeczną aprobatę.

Jednym z narzędzi, których proces wdrażania mamy szansę współcześnie obserwować, jest telefon komórkowy. Proces adaptacji tego wynalazku wydaje się niezwykle interesujący, gdyż dotyczy wielu istotnych sfer życia. To niewielkie urządzenie, najpierw stosowane tylko przez profesjonalistów, bardzo szybko stało się powszechnie dostępne, a dziś nikt nie jest w stanie wyobrazić sobie życia bez niego. Jest to najszybciej rozprzestrzeniający się środek

Adres do korespondencji: ilszym@poczta.onet.pl 
przekazu, najbardziej osobisty i potencjalnie wyzwalający ogromną liczbę nawyków.

Pierwsze modele ruchomych telefonów, jeszcze drogie i nieporęczne, pojawiły się w 1983 r. w Stanach Zjednoczonych, lecz już dwa lata później liczba abonentów telefonii komórkowej wynosiła tam 350 tysięcy, by w 2003 r. wzrosnąć do 150 milionów (Levison 2006a, s. 56). Telefonia komórkowa jako rynek na skalę światową zaistniała w połowie lat dziewięćdziesiątych. W 1991 r. stosunek liczby aktywnych komórek do liczby linii telefonii stacjonarnej wynosił $1: 34$, by w cztery lata później wzrosnąć do $1: 8$, a w 2003 r. po raz pierwszy liczba abonentów sieci komórkowych przewyższyła liczbę abonentów telefonii stacjonarnej. Według danych ITU w $2004 \mathrm{r}^{1}{ }^{1}$ na świecie było 1,198 mld abonentów sieci komórkowych, czyli 27,5 telefonów komórkowych przypadało na stu mieszkańców, a dla telefonów stacjonarnych wskaźnik ten wynosił 19,04. Według GSM Association, organizacji zrzeszającej operatorów telefonii komórkowej, w 2005 r. na całym świecie zakupiono 817 mln nowych telefonów (Kołodziejczyk 2006, s. 7).

\section{Rozproszenie telefonów komórkowych na świecie (w \%)}

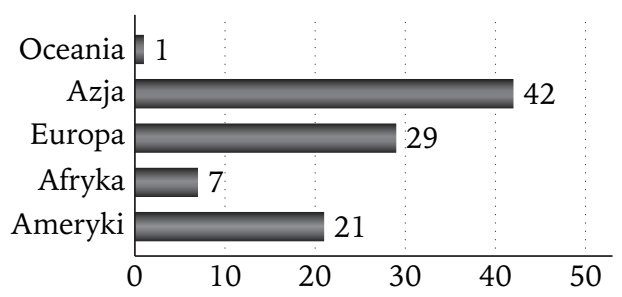

Rozproszenie telefonów komórkowych na świecie w przeliczeniu na stu mieszkańców

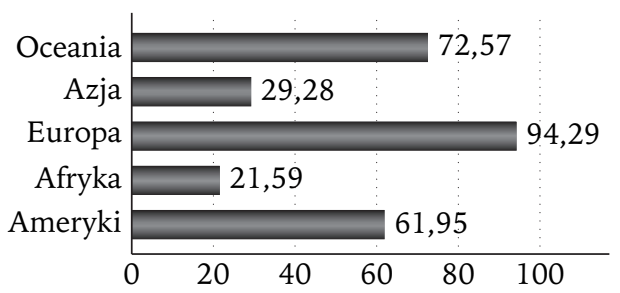

Źródło: www.itu.int; dane z 2006 r.

W Polsce, gdzie pierwsze komórki pojawiły się w 1992 r., obecnie jest ich 30 milionów, przy czym w ciągu ostatnich dwóch lat przybyło 5,5 miliona (Kołodziejczyk 2006, s. 7).

Tak gwałtowne wtargnięcie przenośnego telefonu w życie codzienne musiało mieć swoje skutki. Jak każda zmiana, upowszechnienie telefonu komórkowego powoduje wiele trudności i komplikacji, wymaga bowiem od użytkowników nie tylko nabycia nowych umiejętności, niezbędnych do obsługi tego urządzenia o wciąż rozszerzających się możliwościach, ale także zmiany nawyków. Mimo to już dziś można powiedzieć, że telefon komórkowy odniósł sukces. Coraz mniej jest bowiem białych plam na mapie operatorów sieci komórkowych

${ }^{1}$ Castells i in. 2007, s. 8. Wykorzystuję dane zawarte w książce Castellsa. Dane z 2004 r. są opracowane na podstawie informacji Międzynarodowej Unii Telekomunikacyjnej (ITU), uzupełniane przez autorów badaniami, które nie są dostępne. Tam gdzie jest to możliwe, podaję dane z 2006 r., również na podstawie informacji Międzynarodowej Unii Telekomunikacyjnej dostępnych na stronie: www.itu.int. 
Wskaźniki penetracji polskiego rynku telefonii ruchomej w latach 1997-2007

(liczba aparatów w stosunku do liczby obywateli)

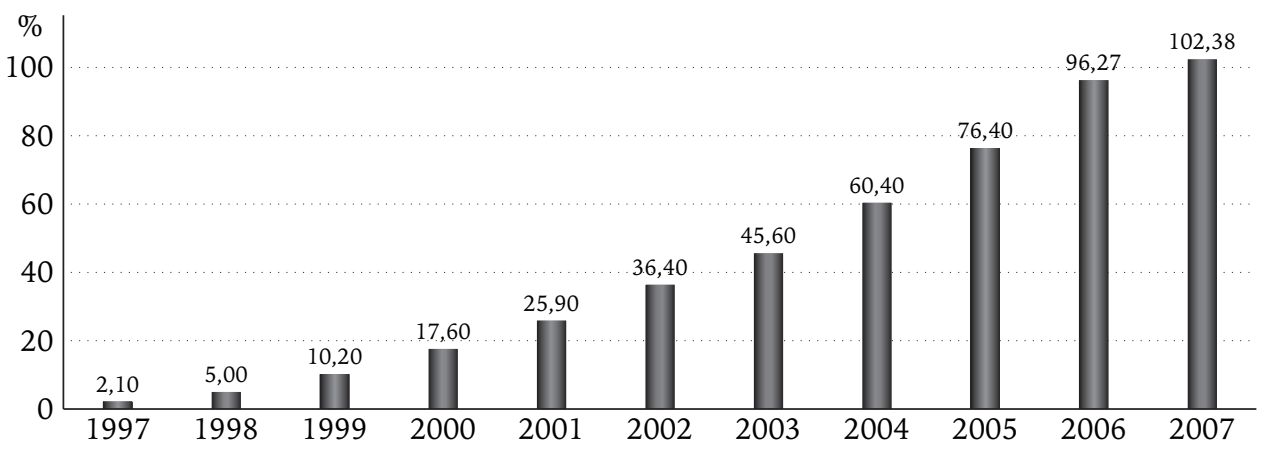

Źródło: Raport Urzędu Komunikacji Elektronicznej o stanie rynku za rok 2006 oraz obliczenia własne na podstawie danych publikowanych na stronach operatorów komórkowych.

i coraz mniej osób mogących pozwolić sobie na ignorowanie komórek, które stopniowo stają się podstawowym narzędziem pracy — umożliwiają wideokonferencje, zapisywanie danych, sprawdzanie poczty elektronicznej. Komórki są też towarzyszem w czasie relaksu dzięki wbudowaniu gier, możliwości oglądania telewizji, odtwarzania muzyki, robienia zdjęć z wakacji czy nagrywania krótkich filmów.

Każdy dostrzega najbardziej elementarne pożytki z ciągłego dostępu do telefonu i podstawowe wady - takie jak ograniczenie sfery prywatności. Mobilny telefon jest jednak wynalazkiem przełomowym, ponieważ daje poczucie bliskości, a zarazem nie obliguje do oficjalnego tonu, umożliwiając przekazywanie różnych wiadomości i emocji osobom, które są daleko, tak jak gdyby siedziały obok. Obok wymiaru osobistej korzyści powszechna obecność mobilnego telefonu ma dużo szersze konsekwencje społeczne. W epoce ponowoczesnej z definicji płynnej - doświadczamy niezauważalnych na pierwszy rzut oka zmian, które jednak znajdują ucieleśnienie w nowych nawykach i w tworzeniu nowych norm i kontekstów. Wiele $z$ nich wprowadził mały aparat pozwalający na komunikację w dowolnym miejscu i czasie.

\section{WSPÓŁDZIAŁANIE W CYFROWEJ SIECI}

Stan określany przez wielu autorów jako ponowoczesność jest etapem zmian zachodzących w organizacji społeczeństwa. Ulrich Beck (2002, s. 164) jako podstawową cechę współczesnego społeczeństwa wymienia strukturalny indywidualizm. Indywidualizacja — jak zauważa — niesie ze sobą pewne straty dla jednostek, które są nie do odwrócenia, takie jak zanik poczucia bezpieczeństwa, pewności, ciągłości rzeczywistości. Zanik poczucia wspólnoty, nawet w związkach rodzinnych wynika - według Becka - z rozpadu norm i hierarchii ról, które okazały się nieadekwatne, gdy najwyższą wartością stała się wolność 
i niezależność. Jednostka zostaje zmuszona do wzięcia odpowiedzialności za samą siebie, samodzielnego tworzenia własnej tożsamości i do redefinicji problemów egzystencjalnych, w czym nie mogą już pomóc ani rola społeczna, ani przynależność grupowa, tak jak w społeczeństwie przemysłowym. Zmiany dotyczą także sfery produkcji - nastąpiło przejście od społeczeństwa przemysłowego, produkującego produkty masowe, do społeczeństwa informacyjnego, w którym głównym „towarem” stała się informacja. Wraz ze stratami, jakie niesie indywidualizacja, rośnie potrzeba „wspólnoty dusz” — stwierdza Beck. Nowa technologia, jaką wprowadzają telefon komórkowy i internet, wydaje się narzędziem, które powstało w odpowiedzi na to zapotrzebowanie, a nowe typy więzi, jakie tworzą się za ich pośrednictwem, są zapowiedzią społeczeństwa nowego typu, które zaczyna się tworzyć.

Zamierzam tu bardziej szczegółowo zanalizować zależności między społecznym użyciem telefonii cyfrowej a procesem zmian, jakich jesteśmy świadkami. Opieram się na informacjach pochodzących z badań przeprowadzanych w różnych częściach świata, ze szczególnym uwzględnieniem Polski jako kraju specyficznego, w którym przeskok do ponowoczesności dokonał się dość gwałtownie, a społeczeństwo nowoczesne wciąż przeplata się z ponowoczesnym, co w sposób niezwykle wyrazisty ukazuje gwałtowność zmiany, jaka zaszła w strukturze społecznej. Sięgam do danych zebranych przez zespół Manuela Castellsa (2007), który uwzględnił światowe statystyki dotyczące wykorzystania i rozwoju sieci telefonii komórkowej, oraz do badań jakościowych przeprowadzonych przez Richa Linga (2004) w Norwegii - kraju, w którym zarówno technologia, jak i poziom nasycenia rynku telefonii komórkowej są na wyjątkowo zaawansowanym poziomie. Cennym źródłem są też badania ankietowe wśród polskiej młodzieży gimnazjalnej i licealnej, przeprowadzone w latach 2002-2003 pod kierunkiem Teresy Sasińskiej-Klas (2003). Jako uzupełnienie powyższych źródeł chciałabym zaprezentować wyniki własnych badań, przeprowadzonych metodą wywiadów pogłębionych. Objęłam nimi 28 osób w wieku od 8 do 80 lat, mieszkańców Warszawy i okolic, o zróżnicowanym pochodzeniu społecznym.

Do opisu i wyjaśnienia przemian zachodzących we współczesnych społeczeństwach stosuję model uspołecznienia Linndy Caporael (zob. Marody, Giza-Poleszczuk 2004, s. 157). W modelu tym zaakcentowana jest rola zanurzenia jednostki w społeczeństwie, a zwłaszcza fakt, że suwerenne jednostkowe decyzje zawsze są podejmowane $\mathrm{w}$ jakimś otoczeniu społecznym, w odniesieniu do konkretnych sytuacji, co kieruje uwagę na współzależność łączącą jednostki w życiu społecznym. Caporael widzi jednostki organizacji społecznej nie jako sztywne byty, lecz jako konfiguracje „powtarzalnych skupień" ${ }^{2}$, odzwierciedla-

2 Pojęcie to jest przez autorkę definiowane jako: nawracające relacje między jednostką analizy a środowiskiem, złożone $z$ hierarchicznie zorganizowanych, heterogenicznych komponentów, mających różne części i skale odtwarzania. 
jących podstawowe rodzaje interakcji ludzkich. Teoria ta jest cenna jako narzędzie analizy, gdyż omija pułapkę opozycji jednostka-społeczeństwo, wskazując na równoległość zmian zachodzących na wszystkich poziomach organizacji oraz rozwiązuje problem reifikacji społeczeństwa jako bytu niezależnego, tkwiącego ponad jednostkami, zmiana bowiem jest tu zawsze procesem „uspołecznionym" i mimo że wyrasta z poziomu najniższego, jej usankcjonowanie i wcielenie następuje, gdy staje się wzorem uznawanym za oczywisty na poziomie całego społeczeństwa.

Linnda Caporael wyróżnia cztery typy powtarzalnych skupień interakcji, uniwersalnych dla wszystkich typów społeczeństw:

Diada - podstawowa jednostka mikrokoordynacji złożona $z$ dwóch elementów (osób, przedmiotów, istot żywych), w ramach której dochodzi do dopasowania działań indywidualnych do powtarzalnego zadania.

Zespół zadaniowy - złożona z 5-8 osób jednostka organizacji (rodzina, grupa pracująca razem), w której pojawia się „rozproszone poznanie”. Jednostki dzielą się indywidualną wiedzą w zakresie niezbędnym do wykonania określonego zadania, wytwarzając wspólną reprezentację fragmentu rzeczywistości związanego ze wspólnym zadaniem. Na tym poziomie zachodzi także socjalizacja.

Grupa bazowa/deme - złożona z około 30 osób bezpośrednio kontaktujących się „każdy z każdym”; do jej podstawowych funkcji należy koordynacja pracy na poziomie zespołów przez kreowanie całościowych obrazów rzeczywistości dzięki negocjacji wiedzy rozproszonej. Tak wytworzony całościowy obraz rzeczywistości narzuca określoną interpretację świata i stanowi podstawę budowy tożsamości społecznej.

Makrogrupa/macrodeme - złożona z około 300 osób, ustanawiana przez okresowe zgromadzenia wspólnot lub ich reprezentantów; w jej ramach dochodzi do wymiany i standaryzacji języka, pojęć, zasad wymiany.

Zmiana relacji, którą chcę analizować, jest wynikiem dłuższego procesu, ale jej przejawy stały się widoczne dopiero jako przedmiot negocjacji na poziomie macrodeme i obecnie jesteśmy świadkami standaryzacji reguł organizacji interakcji. Ponieważ coraz więcej interakcji odbywa się za pomocą telefonu komórkowego, zastosowanie tego narzędzia wydaje się istotnym czynnikiem wpływającym na kształtowanie procesów w ramach powtarzalnych skupień interakcji.

\section{KOMÓRKA - MAEY PRZEDMIOT POŻĄDANIA? MOTYWY ZAKUPU PRZENOŚNEGO TELEFONU}

Telefon komórkowy to narzędzie, które — podobnie jak internet — rozpowszechniło się w tempie, jakim dotąd nie mógł się poszczycić żaden $z$ wynalazków. Co spowodowało tak niewyobrażalny sukces tego urządzenia?

Wśród deklarowanych przyczyn posiadania komórki można wyodrębnić następujące grupy motywów: 
— komórka nabywana do celów zawodowych, dopiero później ujawniają się jej „prywatne” zalety;

- telefony kupowane osobom starszym lub dzieciom, w celu ułatwienia kontaktu i sprawowania opieki nad nimi;

- telefony kupowane z powodu wyjazdów czy dłuższych pobytów poza domem (np. zielona szkoła, kolonie, pobyt w szpitalu, sanatorium itp.), by właściciel był niezależny od publicznych telefonów;

- zakup pod presją otoczenia w odpowiedzi na narzekanie bliskich i znajomych na niedostępność lub „bo wszyscy mają”: ...ja nigdy się nie palitem do tej komórki... [...] No tylko tyle, że kumple narzekali, że nie moga się ze mna skontaktować $i$ wszyscy mieli dookoła mnie i... w sumie tak gtupio byto nie mieć telefonu [M 19].

— brak lub nieefektywna sieć telefonii stacjonarnej.

Wszystko to wydaje się niewystarczające do wytłumaczenia sukcesu tego środka komunikacji, warto więc zastanowić się nad ukrytym motywem wzmacniającym siłę deklarowanych powodów zakupu.

Istnieje powszechne przekonanie - i często racjonalizowany powód zakupu - że komórka zapewnia bezpieczeństwo, i choć tak jest, w praktyce zwykle wykorzystuje się ją do innych celów. Co więcej, przenośny telefon nie zwiększa w sposób bezpośredni bezpieczeństwa, może wręcz zwiększać stopień narażenia na akty agresji, z czego badani doskonale zdawali sobie sprawę, wskazywali bowiem, że komórka co najwyżej przyspiesza możliwość wezwania pomocy w razie nagłych wypadków. Poczucie bezpieczeństwa, jakie przewija się we wszystkich wypowiedziach respondentów, należy jednak rozumieć w znaczeniu szerszym niż tylko to, które jest potrzebne w obliczu bezpośredniego zagrożenia czy wypadku. Żyjemy w społeczeństwie ryzyka — jak twierdzi Ulrich Beck (2002) - ryzyka związanego z niepewnością towarzyszącą nam nieustannie w życiu codziennym, dotyczącą zarówno realnych zdarzeń, jak i sfery psychicznej, w której poziom niepokoju jest znacznie trudniej redukowalny.

Źródłem niepokoju jest nie tylko zmiana społeczna, ale także generowana przez nią zmiana $\mathrm{w}$ rodzinie, gdzie często mamy do czynienia z opcjonalnymi relacjami (Marody, Giza-Poleszczuk 2004, s. 163), które są konsekwencją indywidualnych decyzji, a więc na przykład z multiplikacją dziadków czy takimi rolami, jak ojciec na odległość, ojczym, rodzina własna, męża, byłego męża. Komplikuje się sytuacja dzieci. Generuje to nieustanną niepewność, która powoduje, że jednostka w swych wyborach jest uzależniona od innych, jest — by użyć wyrażenia Davida Riesmana (1996) - zewnątrzsterowna.

Podczas analizy problemu konstrukcji tożsamości warto posłużyć się koncepcją Jeana-Claude’a Kaufmanna (2004), według którego jednostka konstruuje własną tożsamość uwzględniając niejednorodne sfery socjalizacji i sytuację zewnętrzną, jednak konstrukt ten nie jest czymś stałym i niezmiennym, stale się zmienia, zmienia się także myślenie jednostki o samej sobie, zachowuje ona jednak wrażenie „bycia taką samą”. Jedyną formą, jaka pozwala zarządzać tymi 
sprzecznymi logikami, jest opowiadanie - narracja nadająca sens zdarzeniom, w których się uczestniczy (Gergen 1994, s. 249).

Telefon komórkowy ze swej natury w pełni wpisuje się $\mathrm{w}$ tę rozbitą przez procesy indywidualizacyjne rzeczywistość. $Z$ jednej strony nasila krzyżowanie się różnych narracji rozwijanych przez jedną osobę, co można zaobserwować choćby wówczas, gdy na spotkaniu towarzyskim ktoś odbiera służbowy telefon - zmienia się wówczas ton jego głosu, sposób budowania zdań, a nawet postawa i gestykulacja. Te zewnętrzne oznaki przejścia w inny świat wskazują trudność, jaką nastręcza stosowanie różnych narracji odpowiednio do różnych czynników zewnętrznych, gdy przestrzenność relacji zostaje zaburzona. Przenośny telefon $\mathrm{w}$ ten sposób generuje niepewność znaczeniową, a więc powoduje obawę jednostki o własny wizerunek, ponieważ zderza dwie narracje, zakłócając tok relacji toczonej w realnej przestrzeni i narażając rozmawiającego przez komórkę na utratę twarzy. Dlatego dzwonek telefonu w większości wypadków powoduje wycofanie się z towarzystwa, odejście od niego w przestrzeni (Ling 2004, s. 70). To dlatego, moim zdaniem, komórka jest krytykowana jako odpowiedzialna za rozpad sfery społecznej — burząca spójność jej narracji.

$\mathrm{Z}$ drugiej strony komórka jako nośnik przełamujący ograniczenia przestrzenne pozwala na bezpośrednie skonfrontowanie własnej narracji w relacjach z innymi, obarczone o wiele mniejszym ryzykiem niż w realnej konwersacji, ponieważ nieporozumienia, niedopowiedzenia są akceptowalne jako coś, co się zdarza i wynika z zapośredniczenia mowy bez transmisji obrazu i braku dostępu do kontekstu, w jakim znajduje się rozmówca. Możliwość wyciągnięcia telefonu i konsultacji decyzji z kimś bliskim pozwala obniżyć stopień niepewności i choćby iluzorycznie upewnić się, że decyzja jest słuszna lub zmienić ja, jeśli nie znajdzie akceptacji owych znaczących innych, do których można się odwołać. W rozmowie telefonicznej o wiele łatwiejsze jest także wycofanie się z niewygodnej konwersacji bez utraty twarzy, dzięki takim formułom jak: „nie mogę teraz rozmawiać”, „muszę kończyć, porozmawiamy potem” itp. Komórka pozwala także na efektywniejsze zarządzanie narracjami, ich lepsze dopasowanie do sytuacji zewnętrznej: „Po prostu, lepiej jest zadzwonić niż iść do kogoś i powiedzieć mu to samo" [M 16].

Można przypuszczać, że to właśnie niepewność co do obowiązujących norm, wynikająca $z$ zachodzącej we współczesnym świecie zmiany, brak jasnych wyznaczników statusu i zachowań powodują, że telefon komórkowy znalazł tak poczesne miejsce $\mathrm{w}$ życiu społecznym. Mamy do czynienia $z$ fragmentaryzacją przestrzeni i fragmentaryzacją sieci znajomych, a komórka pozwala na powrót zintegrować te dwie sfery, paradoksalnie jednak wyabstrahowując jednostkę $z$ jej fizycznego otoczenia. W sytuacji gdy wspólnoty przypisania zamieniają się we wspólnoty wyboru, niezależne od powiązania przestrzennego, komórka pozwala na to, by rozrzucone w fizycznej przestrzeni osoby bliskie i członkowie wspólnoty mieli nieustanne poczucie możliwości bezpośredniego kontaktu. Spaja to grupy, dając ich członkom poczucie bezpieczeństwa zapewniane przez 
świadomość bliskości wsparcia na wyciągnięcie ręki, co ilustruje następująca wypowiedź: ...ostatnio taka ciężka sytuacja była... czułam się niespokojna i smutna, $i$ zadzwonitam do Adama, bo akurat byt pod ręka [K 24_2].

Stąd też tak często pojawiający się w wywiadach zwrot „na wszelki wypadek", którego rozumienie jest bardzo szerokie. Może oznaczać na wypadek, gdyby coś się stało, ale także na wypadek, gdybym potrzebował wsparcia lub gdyby ktoś go ode mnie potrzebował. Ta dwuznaczność nie zawsze jest uświadamiana czy artykułowana przez respondentów, ale wiązanie bezpieczeństwa $z$ komórką jest jednoznaczne. Jedna z respondentek stwierdziła, że zawsze, nawet wychodząc do sklepu, bierze ze sobą komórkę „na wszelki wypadek”, bo ktoś mógłby dzwonić. Pytana przeze mnie, z jaką sytuacją to wiąże, przytoczyła następujący przykład: No trochę się denerwuję, denerwuję się, że ktoś może zadzwonić, córka na przykład albo... a ja nie mam komórki, no ale wtenczas szybko przychodzę do domu [K 60]. Nie spodziewa się przy tym, że córka będzie dzwonić w sytuacji niebezpieczeństwa, raczej, że poprosi, jak to się często zdarza, o zaopiekowanie się wnuczką. „Wszelki wypadek” w tej sytuacji oznacza więc konkretną potrzebę pomocy.

\section{CIEMNE OBLICZE TECHNOLOGII}

Przenośny telefon, jak każde narzędzie, ma także wady. Niezależnie od ogromnego wkładu w podnoszenie poczucia bezpieczeństwa komórka jest źródłem poczucia zagrożenia, rozumianego na wiele sposobów.

Respondenci często wskazywali na obawę, że komórka może sprowokować napad. Świadomość tę mają zarówno dorośli, jak i dzieci, choć ostatnio zagrożenie takie maleje, przede wszystkim w wyniku znacznego obniżenia cen aparatów, które są dostępne w systemie pre paid nawet za symboliczną złotówkę, oraz możliwości blokady telefonu i jego lokalizacji, co utrudnia ponowne włączenie kradzionego urządzenia w obieg rynkowy.

$\mathrm{Na}$ Zachodzie za jedno z największych zagrożeń wiążących się z komórką jest uznawany wypadek spowodowany rozmową przez telefon podczas kierowania samochodem (Ling 2004, s. 50). W Polsce jest ono bardzo słabo uświadamiane. Łatwo można zaobserwować, że przepisy zezwalające na rozmowę w samochodzie pod warunkiem korzystania $z$ zestawu nie absorbującego rąk, nie są respektowane. Co więcej, tylko jeden spośród respondentów poruszył ten problem $\mathrm{w}$ rozmowie i to raczej traktując takie zachowanie jako normę, część kultury osobistej, niż źródło zagrożenia: A szczególnie naganne jest używanie telefonów komórkowych podczas jazdy samochodem [...] to przecież nagminne i nie tylko faceci z ogolona gtowa, ale i eleganckie panie [M 65].

Rich Ling (2004, s. 49) przytacza badania, według których niemal co czwarty $z$ uczestników wypadku rozmawiał przez komórkę w ciągu dziesięciu poprzedzających go minut. Mimo powyższych danych i świadomości zagrożenia około jednej trzeciej posiadaczy przenośnych telefonów przyznaje się do dość regu- 
larnego korzystania z nich podczas jazdy (Ling 2004, s. 51). Przyczyną tej sprzeczności może być fakt, że mimo iż kierowanie samochodem jest podporządkowane ścisłym regułom, jednocześnie jest to czynność silnie zrutynizowana.

Także ułatwienie koordynacji codziennych zadań kryje w sobie zagrożenia, na przykład że praca zawłaszczy czas wolny - pod pretekstem wymogu elastyczności zmusza się pracownika do bycia wciąż dostępnym.

Komórka jako narzędzie koordynacji może też być wykorzystywana przez przestępców i terrorystów, co pokazały wydarzenia z września 2001 r. czy zamachy w Madrycie i Londynie, gdy telefon nie tylko służył synchronizacji działań przestępczych, lecz także jako detonator materiałów wybuchowych. W celu obrony przed takimi sytuacjami wiele państw wprowadziło obowiązek automatycznego zapisu rozmów i SMS-ów oraz nakaz jego przechowywania przez minimum dwa lata. Taki zapis ma chronić społeczeństwo przed terrorystami, gangami narkotykowymi czy korupcją, rozciąga jednak nadzór na wszystkich obywateli, każdy może być skontrolowany — każdy, anonimowo lub nie, znajduje się w bezprzewodowym panoptykonie, $z$ którego trudno się wydostać pozostając „w sieci”. Co więcej, informacje na temat wykazu rozmów, ich zapisu czy lokalizacji konkretnej osoby mogą być wykorzystane przez strategów marketingowych do manipulacji klientami lub przez osoby prywatne do śledzenia poczynań przyjaciól, partnerów, członków rodziny.

Innym powszechnie uświadamianym zagrożeniem generowanym przez komórki jest emisja fal radiowych i elektromagnetycznych, zarówno przez aparaty, jak i stacje nadawcze. Jest to zagrożenie typowe dla „społeczeństwa ryzyka” (Beck 2002, s. 74) - niewidzialne, trudne do zmierzenia i tak naprawdę nie wiadomo, jaki jest jego długofalowy wpływ na organizm ludzki. Badania medyczne nie wskazują jednoznacznie na szkodliwość fal w krótkim okresie, część badaczy wysuwa jednak opinie, że długoterminowy wpływ fal radiowych może powodować bezpłodność, migreny itp. Wywołuje to protesty przeciw ustawianiu naziemnych stacji komórkowych w pobliżu domostw. Kwestia określenia bezpiecznego poziomu emitowanego przez nie promieniowania jest jednak dyskusyjna, ponieważ ze względu na brak jednoznacznych danych naukowych przepisy kształtowane są dość dowolnie i są konstruowane społecznie. Jak trafnie zauważa Ulrich Beck (2002, s. 84): „Kto ogranicza zanieczyszczenia, ten równocześnie je dopuszcza. To, co jest jeszcze możliwe, jest na mocy społecznego definiowania "nieszkodliwe», niezależnie od stopnia swojej faktycznej szkodliwości". Problem ten ilustruje analiza konfliktu dotyczącego budowy naziemnej stacji bazowej przeprowadzona przez Piotra Stankiewicza (2007). Gdy zawiódł ekspercki model regulacji konfliktu, mieszkańcy zażądali od właściciela stacji dowodów nieszkodliwości stacji, co z punktu widzenia racjonalności naukowej jest nielogiczne, ponieważ „zgodnie z zasadami metodologii nauk nie sposób udowodnić nieistnienia czegoś, można jedynie nie stwierdzić faktu występowania" (Stankiewicz 2007, s. 105). W tej kwestii technologia telefonii 
komórkowej zmusza zarówno naukowców, jak i nieekspertów do poszukiwania nowych strategii porozumienia.

Komórka przyczyniła się do upowszechnienia nowego typu zagrożenia, dzięki coraz większej liczbie wbudowanych narzędzi i digitalizacji aparatów ułatwiając różne przestępstwa. Pogrupowano je w trzy kategorie (Castells i in. 2007, s. 118).

Robienie zdjęć nieświadomym tego faktu osobom: w zatłoczonych środkach komunikacji, sklepach lub w ubikacjach, przebieralniach sklepowych czy na basenach. W Japonii stało się to tak uciążliwe, że policja stosuje wysokie grzywny (nawet do 4200 dolarów amerykańskich). W łaźniach miejskich zakazane jest używanie telefonów $z$ wbudowanym aparatem fotograficznym, produkuje się komórki z głośnym dźwiękiem sygnalizującym zrobienie zdjęcia.

Tak zwana „cyfrowa kradzież” — polegająca na fotografowaniu drogich publikacji w księgarniach, co przyczyniało się do spadku ich sprzedaży.

Sytuacje, zdarzające się głównie w szkole, gdy komórka pośrednio staje się środkiem przemocy. Akty przemocy wobec kolegów są filmowane, a potem publikowane $\mathrm{w}$ internecie lub przesyłane innym, przy czym często to właśnie możliwość opublikowania całego zajścia jest dla nastolatków najbardziej atrakcyjna. Przypadki pobicia kolegów w klasie nagrane kamerą z komórki i opublikowane $\mathrm{w}$ internecie doprowadziły do zakazu posiadania przenośnych telefonów z wbudowaną kamerą w wielu szkołach w Hongkongu i Wielkiej Brytanii, gdzie zjawisko to wystąpiło na dużą skalę i zyskało nawet odrębną nazwę - happy slapping. Mimo podejmowania środków ostrożności zdarzenia przemocy powiązanej z filmowaniem wciąż się pojawiają, co niejednokrotnie ma drastyczny przebieg, jak w 2007 r. w Polsce, gdy w jednym z gdańskich gimnazjów koledzy nagrali komórką film, na którym udają, że gwałcą koleżankę z klasy, a załamana dziewczynka następnego dnia popełniła samobójstwo.

Telefon komórkowy jest więc nośnikiem wielu zagrożeń swoistych dla współczesnej cywilizacji, zagrożeń potencjalnych i niewidzialnych. Owo potencjalne ryzyko, bardzo często wyparte ze świadomości użytkowników, jest nieusuwalne, ponieważ jak wskazuje Beck (2002, s. 105) jego zniesienie oznaczałoby całkowitą zmianę stylu życia, w wielu przypadkach zaś przenośny telefon jest tylko jednym $z$ narzędzi umożliwiających rozprzestrzenianie się ryzyka - rezygnacja $z$ produkcji telefonów $z$ aparatem nie rozwiąże problemu uwaga zostanie skierowana $z$ pewnością na inne środki przekazu.

\section{BOGACTWO ZASTOSOWAŃ. SPOŁECZNE WYKORZYSTANIE TELEFONU KOMÓRKOWEGO W ŻYCIU CODZIENNYM}

Niezależnie od powodów zakupu i swoich wad raz nabyty telefon staje się nieodłącznym elementem życia codziennego, bez którego trudno się obejść: Czy SMS-em czy rozmowa no niestety... to jest teraz moja prawa ręka [K 24_2]. Co prawda, wiele osób deklaruje, że mogłoby żyć bez komórki, jednak równie dużą 
grupę, może nawet większą, stanowią ci, którym bez niej trudno żyć. Wydaje się, iż wypowiedzi, że komórka $\mathrm{w}$ zasadzie nic nie zmieniła $\mathrm{w}$ życiu, że bez problemu można bez niej funkcjonować, nie do końca oddają rzeczywistość.

Oczywiście, nie chciałabym sugerować, że życie bez komórki jest niemożliwe. Jak najbardziej można się bez niej obyć i funkcjonować całkiem sprawnie, choć nie bez pewnych niedogodności. Istota rzeczy polega na tym, że komórka zmienia nasz sposób myślenia o świecie, czasie i przestrzeni. Przekazanie każdej informacji, niezależnie od miejsca pobytu i sytuacji, jest nie tylko możliwe, ale i oczywiste. Zmieniło to w sposób znaczący nasze zachowania, postrzeganie świata oraz dotyczących go wiadomości w porównaniu z niedawnym okresem, gdy bezpośredni kontakt nie był tak łatwy. Jak wiele codziennych spraw jest dziś załatwianych przez komórkę, często nie zauważa sam jej użytkownik. Zazwyczaj nie są to czynności, których nie można zorganizować w inny sposób, bez pośrednictwa przenośnego telefonu — załatwić przez telefon stacjonarny czy po prostu osobiście - różnica polega na tym, że w takich sytuacjach po komórkę sięga się odruchowo.

Najbardziej uzależnia od komórki wygoda, o czym świadczy fakt, że jest ona wyłączana niechętnie, tylko w szczególnych sytuacjach.

Można wyróżnić trzy grupy zachowań. Najczęściej komórka jest włączona cały czas, $z$ wyjątkiem ważnych spotkań lub pobytu w miejscach, w których przyjęte jest ją wyłączać, jak kościół, teatr. Jest też grupa osób, przeważnie starszych, które nigdy nie wyłączają komórki, a tam, gdzie ewentualny dzwonek mógłby przeszkadzać, po prostu nie biorą jej ze sobą: Może nie wytaczam, tylko po prostu nie biore go ze soba, na przyktad jak idę do kościota. [...] Spotkania typu konferencja, spotkania ważne... Dlatego że jeśli ktoś ma jakaśs sprawę, to wracam $i$ widze tyle rozmów nieodebranych, a jak ktoś coś ma ważnego to wysyta SMS-a, a ja go później moge sobie odczytać [M 65]. Trzecią grupę stanowią ludzie młodzi, którzy wyciszają telefon, jeśli okoliczności tego wymagają, a wyłączają go tylko w skrajnych wypadkach: Bardzo rzadko. Wytaczam tylko dźwięk, nawet jak idę do kina czy do teatru... ostatnio wytaczytam telefon $w$ nocy, ponieważ o drugiej $w$ nocy $k$ toś się do mnie dobijat, numer nieznany i robit to tak... namiętnie... że po prostu nie dało rady, musiałam wyłączyć, ale to byt ostatni raz od pót roku... [K 24_2].

Urządzenie, które stało się tak nieodłącznym towarzyszem życia codziennego, popularność swą zawdzięcza użyteczności. Jako główne zalety ruchomych telefonów są postrzegane możliwość planowania i zarządzania relacjami społecznymi. Według badań sondażowych przeprowadzonych w 2000 r. w krajach europejskich ${ }^{3}, 69 \%$ respondentów uznało, że komórka jest bardzo użyteczna w zarządzaniu sprawami rodzinnymi i społecznymi, 70\% stwierdziło, że komórka pozwala na stały kontakt z rodziną i przyjaciółmi. Dane te znajdują potwierdzenie $\mathrm{w}$ przeprowadzonych przeze mnie w badaniach. W wypowiedziach

\footnotetext{
3 Dane pochodzące z bazy Eurescom P903 przytaczam za: Ling 2004, s. 59.
} 
na temat spraw najczęściej załatwianych przez komórkę bardzo często pojawiał się zwrot „sprawy codzienne”, „zakupy”. Ponieważ badanie to okazało się niewystarczające do wyjaśnienia, co kryje się za tym oczywistym stwierdzeniem, warto sięgnąć po sondaże przeprowadzone na większych i bardziej kulturowo zróżnicowanych grupach respondentów.

Rich Ling (2004) stawia tezę, iż do oszałamiającej kariery komórki przyczyniła się możliwość dopasowywania za jej sprawą działań już w trakcie ich wykonywania. Mobilny telefon pozwala znacznie oszczędzać czas, gdyż podczas zakupów czy jazdy samochodem można załatwić sprawy służbowe, umówić się na spotkanie czy na wizytę lekarską, co oznacza, że czas, który w przeciwnym razie byłby „zmarnowany”, można przeznaczyć na inne czynności, wymagające większego zaangażowania. Dzięki komórce wszystkie czynności związane $z$ prowadzeniem domu mogą być załatwione sprawniej i szybciej. Jest to szczególnie istotne $\mathrm{w}$ stosunkach rodzinnych, ponieważ pozwala na elastyczny podział obowiązków, w zależności od okoliczności. Ta rola komórki wydaje się wyjątkowo cenna, gdy oboje partnerzy pracują, pozwala bowiem na sprawowanie opieki nad małymi dziećmi „na odległość, przez zapewnienie im komfortu kontaktu $\mathrm{z}$ rodzicami $\mathrm{w}$ każdym momencie, ułatwia także kontrolę bardziej samodzielnych nastolatków. Taki sposób organizacji życia powoduje dużo głębszą zmianę, niż mogłoby się wydawać. „Pojawienie się TK [telefonu komórkowego] — pisze Roch Sulima (2007, s. 210) - wyraźnie ogranicza lub wręcz eliminuje poobiednie lub wieczorne "wiadomości» domowe. Wymieniane są one na bieżąco w ciągu dnia, wzajemnie zdaje się sprawę z przebiegu dnia członków rodziny. Brak takich informacji może nawet niepokoić". Zygmunt Bauman (2003) idzie w ocenie sytuacji dalej - stwierdza, że mimo iż ludzie potrafią przez telefon drobiazgowo relacjonować powrót do domu pociągiem, po powrocie zamykają się we własnym pokoju. Czy te diagnozy są trafne? $\mathrm{Z}$ pewnością fakt, że nie ma potrzeby zdawać relacji $z$ przebiegu dnia po powrocie do domu, ma wpływ na charakter rozmów w rodzinnym gronie, nie oznacza zaniku potrzeby rozmowy. Jednak sformułowanie bardziej uprawnionych wniosków wymagałoby przeprowadzenia głębszej analizy zachowań, co wydaje się trudne ze względu na prywatność sfery rodzinnej.

Komórka w istotny sposób wpłynęła na wcześniej silnie zakorzenione w naszej kulturze normy, w tym normę niespóźniania się. W sondażu przeprowadzonym w kilkunastu krajach europejskich przez Eurescom 92\% ankietowanych zgodziło się ze stwierdzeniem: „Użycie telefonu komórkowego pomaga powiadomić innych, że jesteś spóźniony” (zob. Ling 2004, s. 75). Przed "epoką” ruchomych telefonów spóźnienie odbierane było jako brak szacunku wobec osoby, która musiała czekać, i źle świadczyło o spóźniającym się. Obecnie norma ta uległa złagodzeniu, osoba czekająca nie czuje się urażona, a spóźniający się zachowuje twarz, jeśli uprzedzi o spóźnieniu podając jego przyczynę, wówczas bowiem obie strony mogą tak dopasować swe działania, by 
skutki spóźnienia były jak najmniejsze. Ogromnym nietaktem jest natomiast spóźnienie bez uprzedzenia.

Kate Fox w raporcie zatytułowanym Evolution Alienation and Gossip: The Role of Mobile Telecomunications in the 21st Century (2001) postawiła tezę, iż komórka stanowi narzędzie ułatwiające plotkowanie - czynność, która nie tylko pozwala wymieniać bieżące informacje o życiu społecznym, ale także łagodzi napięcia i stres w sfragmentaryzowanym i alienującym świecie. Plotka jest tu rozumiana jako wymiana informacji o życiu i relacjach ludzkich, zazwyczaj uzupełniona opinią lub odczuciami powiązanymi z tą informacją (przy czym mimo różnej formy wypowiedzi, plotkują zarówno mężczyźni, jak i kobiety (Dunbar 1996)). Dzięki komórce w każdym miejscu, o każdej porze możliwe jest podzielenie się emocjami - wymiana wiadomości o znajomych, oderwanie się od realnej sytuacji. Rozmowa telefoniczna lub SMS może przekazywać plotkę lub być wstępem do niej. Jak stwierdza Kate Fox (2001, s. 10), „codzienne frustracje współczesnego świata mogą być złagodzone przez odrobinę "werbalnego iskania», przez rozmowę lub tekst". Jako potwierdzenie tej tezy autorka przytacza następujący cytat z przeprowadzonych przez siebie wywiadów fokusowych: „Nie wolno mi wykonywać prywatnych telefonów w pracy, ale mogę zadzwonić do mojej siostry na komórkę i możemy pogadać o rodzinie, chłopakach i relacjach. Nawet jeśli siedzę za biurkiem, wydaje się jakbym była w domu, ten rodzaj ciepłego uczucia - to tak, jakbym mogła uciec z pracy w inny świat, wiesz? Bardziej przyjazny" (s. 11).

Czy w Polsce także plotkujemy? Z pewnością tak, skoro jest to czynność swoista dla gatunku ludzkiego, choć respondenci niechętnie się do tego przyznają, zwłaszcza że słowo „plotka” ma negatywne konotacje znaczeniowe i często kojarzone jest z obmową. Na fakt, że społeczna wymiana informacji odbywa się także przez komórkę, mogą wskazywać następujące wypowiedzi:

Czasem też mam tak jakby chęć zadzwonić do kogoś, spytać po prostu co się dzieje, co stychać [M 16].

Dzwonię wtedy kiedy się stęsknię, dzwonię wieczorem i pytam się, „kochanie, co stychać u ciebie" albo "jak ci minąt dzień" albo: co robisz, no. [...] Urodziła mi się wnuczka i musze się tym koniecznie z kimś podzielić [K 53].

Jak się coś wydarzy to [dzwonię] do przyjaciótki, bo wiadomo, że nie do każdego, ale do przyjaciótki napisać SMS-a czy zadzwonić, wiadomo, podzielić się emocjami [K 16_1].

Szczególna rola komórki jako środka natychmiastowego potencjalnego kontaktu z bliskimi w celu złagodzenia stresu przez luźną pogawędkę ujawnia się wówczas, gdy zabraknie przenośnego telefonu. Warto zaznaczyć odrębność dwóch sytuacji: jednej - gdy świadomie podejmuje się decyzję o wyłączeniu telefonu, by nie przeszkadzał w pracy, nauce czy odpoczynku, i drugiej - gdy na przykład rozładuje się bateria, a posiadacz komórki odczuwa zdwojony stres, gdyż sytuacja nie jest pod kontrolą. Zdezorientowanie i niepewność doświadczane przezeń wówczas trudno opisać i jednoznacznie sklasyfikować. 
Jeśli przyjmie się tezę Kate Fox, to należałoby je postrzegać jako związany z wyobcowaniem w tłocznym otoczeniu stres, który się kumuluje, gdyż nie sposób rozładować go przez kontakt z kimś znajomym.

Zapomnienie komórki zwykle pozostaje zdarzeniem żywym w pamięci respondentów, którzy są w stanie je przytoczyć, jednoznacznie klasyfikując jako doświadczenie niemiłe. Oto charakterystyczne opowieści o sytuacji braku telefonu:

To było straszne. Szczególnie jak zapominam telefonu, to jest straszne, bo nie moge sie $z$ nikim skontaktować [K 16_1].

Nie byto to specjalnie mite, $z$ tego względu że, no... jest to przyzwyczajenie, że zawsze moge dostać jakass wiadomość, która jest ważna, pilna i tak dalej i naraz jestem jak gdyby trochę poza tą siecia [M 25].

Czułem się taki jakby odosobniony, zero kontaktu ze mna. Jestem uzależniony od telefonu $i$ czasami jak na przykład go nie mam, to czuje się taki nieswój. [...] Każdy ma telefon $i$ to jest po prostu... no... podstawowa rzecz. [...] Znaczy... przez telefon zatatwiam większość spraw... [M 16].

Warto zauważyć, że w powyższych wypowiedziach przewija się motyw pustki, poczucie osamotnienia, mimo że osoby te znajdowały się wciąż wśród ludzi, na przykład w szkole, w pracy, były jednak przeświadczone, że są od czegoś odcięte.

\section{RUCHOMY TELEFON — RUCHOMA ETYKIETA}

Istniejący w naszej świadomości od co najmniej stu lat telefon z kablem został otoczony pewnymi normami zachowań włączonymi w zestaw powinności i prawideł obowiązujących kulturalną osobę. Komórka podziela $z$ nim niektóre funkcje, jednak zupełnie odmiennie kształtuje sytuację rozmowy. Dzwoniąc na telefon stacjonarny zawsze dzwoni się w jakieś miejsce, rozmowa odbywa się w zdefiniowanym otoczeniu, w którym panują określone reguły. Gdy dzwoni się do kogoś do domu, nigdy nie wiadomo, który z domowników odbierze telefon, należy więc się przedstawić, by wiedział, z kim rozmawia, i poprosić określonego rozmówcę do telefonu. Na komórkę dzwoni się do konkretnej osoby, zwykle jest to ktoś znajomy i nie trzeba się przedstawiać, wie bowiem, kto dzwoni, zanim odbierze, co więcej, może zdecydować, czy chce rozmawiać z dzwoniącym, czy nie. Nie obowiązuje też kryterium pory, po której nie wypada dzwonić - jeśli ktoś sobie nie życzy rozmów, to może wyłączyć komórkę lub jej nie odbierać, a jeśli informacja jest pilna, dzwoniący ma do dyspozycji asynchroniczne formy przekazu: pocztę głosową lub SMS. Rozmowa przy użyciu komórki staje się dużo mniej sformalizowana.

Specyficzną cechą przenośnego telefonu jest to, że swym niespodziewanym dzwonkiem zakłóca on tok bieżących działań, wkraczając przy tym niejako w inną społeczną rzeczywistość, zakłócając porządek czynności, zdarzeń 
i hierarchii. Użycie telefonu komórkowego staje się problematyczne w dwóch kontekstach: w miejscach, gdzie panują szczególnie dokładne, formalne lub nie, regulacje co do zachowania, jak teatr, kino, szkoła, urząd, kościół itp., oraz wówczas gdy brak jednoznacznych unormowań, na przykład w trakcie nieformalnych rozmów, spotkań towarzyskich, lub w sytuacjach definiowanych częściowo jako prywatne, częściowo jako publiczne, na przykład w autobusie, w parku, w barze.

Telefon służbowy — jako ważny — powinien i może być odebrany prawie zawsze, $z$ wyłączeniem pewnych wyjątkowych sytuacji. Tu nie ma wątpliwości służbowy znaczy pilny i w godzinach pracy należy taki telefon odebrać. Większe problemy z kwalifikacją telefonu „do odebrania” zaczynają się, gdy pracownik posiada obok służbowego telefon prywatny lub gdy na służbowy telefon przychodzą rozmowy prywatne. Wobec braku jednoznacznych norm postawy są różne. Na przykład część ankietowanych przeze mnie osób uznawała, że w wyjątkowej sytuacji można taki telefon odebrać, lecz nie należy kontynuować rozmowy: $W$ pracy to wiadomo, sprawy prywatne to załatwia się szybciutko, tak mi sie wydaje, że nie powinno się dyskutować godzine przez telefon [K 37]. Zauważalne są też głosy mniej restrykcyjne, zwłaszcza wśród młodszego pokolenia, dopuszczające rozmowy, jeżeli nie koliduje to $z$ wykonywaniem obowiązków. Według moich obserwacji, liczba rozmów prywatnych w godzinach pracy nie zależy od wieku, choć wypowiedzi osób powyżej pięćdziesięciu lat są bardziej surowe. Oprócz sytuacji oczywistych: Niech by szef byt [w pokoju], czy coś... to wiadomo przecież, $\dot{z} e$ nie będę $w$ tym czasie przez telefon na osobiste sprawy rozmawiała [K 67], reszta wydaje się negocjowalna, oczywiście w granicach rozsądku: Uważam, $\dot{z} e$ jeżeli ktoś korzysta $z$ telefonu $w$ pracy, to powinien znaleźć na to wygospodarowany przedtem czas, bo praca jest praca, nie można rozmawiać w pracy [M 24].

Warto zauważyć, że owa elastyczność postrzegania prywatnych rozmów bardzo często nie zależy od oficjalnych przepisów, ale od relacji między pracownikami, co w sposób następujący usiłowała wskazać jedna $z$ pracujących respondentek: To zależy też w jakiej sytuacji, prawda, bo jeżeli jest się we wspólnym pokoju $i$ jest taka sytuacja bardziej, że ludzie, którzy sa w tym pokoju... bardziej tak koleżeńsko się czuja pomiędzy soba, to nawet jeżeli dzwoni ten telefon prawda, to może spokojnie odebrać. A na przykład jeżeli już jest się z osoba na przykład wyżej postawiona, to albo na przykład... no wypada powiedzieć przepraszam i odebrać ten telefon, $i$ powiedzieć, że na przykład nie moge teraz rozmawiać, jeżeli to jest coś bardzo pilnego, to wypadałoby wyjść po prostu. Tak mi sie wydaje... zależy jakie to sa stosunki panujące pomiędzy pracownikami [K 24_1].

Bardzo często możliwość korzystania z telefonu w pracy zależy od jej charakteru. W wielu przypadkach nie zgadza się na to pracodawca. Trudno też sobie wyobrazić, by w niektórych zawodach pracownik wyjmował komórkę i rozmawiał $\mathrm{w}$ trakcie wykonywania pracy, tak jest między innymi $\mathrm{w}$ sektorze usług - kelnerzy, barmani, recepcjonistki, kasjerki to pracownicy, których nie wolno nam oglądać z komórką w ręku. Są też zawody, w których mimo 
powszechnie panującego przekonania, że telefon nie powinien być używany, norma ta jest przestrzegana dużo mniej restrykcyjnie. Na przykład nauczycielom, wykładowcom czy biznesmenom zdarza się odebrać komórkę w trakcie zajęć, chociaż uznawane jest to za nieeleganckie.

Największe kontrowersje budzi komórka w szkole, zwłaszcza w młodszych klasach przenośny telefon zaczął stanowić element gry z nauczycielem, który często nie radził sobie w tej sytuacji, zwłaszcza że odebranie komórki zuchwałemu nastolatkowi spotykało się z protestami rodziców, ponieważ telefon był traktowany (i nadal jest) jak przedmiot osobisty. Kiedy jednak zaczęło dochodzić do incydentów, podczas których w trakcie lekcji obrażano nauczyciela lub dokonywano aktów przemocy i całą sytuację nagrywano za pomocą kamery umieszczonej w komórce, wydano administracyjny zakaz używania telefonu komórkowego na terenie szkól.

Nastolatki mają świadomość, że odbieranie telefonu czy SMS-ów podczas lekcji jest nietaktem i że, podobnie jak $z$ rozmową $z$ kolegą $w$ ławce, należy z tym poczekać do przerwy, jednak raczej trudno im oprzeć się pokusie sprawdzenia wiadomości i odpisania na nią, skoro SMS nie przeszkadza osobom z otoczenia. Mimo zakazu młodzi ludzie przyznają otwarcie: Jest zakaz, ale na przykład ja mam wyciszony telefon, jak dostaje SMS-a, to po kryjomu jakoś tam odczytuje. [...] Generalnie, jak mi zadzwoni, to nauczyciel zabiera telefon, ale jak coś zagadam, że zapomniałam wyłaczyć albo że mama dzwonita no to tam... przymyka oko [K 16_1]

Przywykłym do bycia w stałym kontakcie nastolatkom raczej trudno narzucić zakaz używania telefonów w szkole. Jak stwierdziła ankietowana licealistka: Nawet jeśli on będzie, to i tak będziemy korzystać z tych telefonów [K 16_2].

Trudno negatywnie oceniać dzieci i młodzież, skoro nawet na uczelniach, gdzie mamy do czynienia z dorosłymi ludźmi, od których oczekuje się przestrzegania ustalonych zasad współżycia, dochodzi do sprawdzania wiarygodności zakazów i prób ich omijania. Gdy jednak jeden z profesorów wykazał się liberalnym podejściem do kwestii i zezwolił na odbieranie SMS-ów na wykładach, sam bowiem często korzystał z telefonu podczas zajęć, postępowanie takie nie spotkało się z aprobatą władz uczelni, a przez studentów, choć też korzystają z telefonów, było odbierane raczej negatywnie: No to jest ewenement, po prostu, dosyć rzucajacy się $w$ oczy. Mi to przeszkadza $i$ bym sie na to nie zgodzita jako wykładowca... ale wykładowca był zmuszony wyższa koniecznościa i jest ścigany teraz, ̇̇e na to pozwala [...] [K 24_2].

Jednoznacznie negatywnie jest oceniane korzystanie $z$ komórki jako narzędzia „ściągania”, które w Polsce, choć powszechnie potępiane, jest jednak mocno ugruntowanym elementem szkolnej edukacji. Trudno się więc spodziewać, żeby młodzi ludzie, wykazujący niesłychaną inwencję w wynajdywaniu sposobów na skuteczne ściągi, nie sięgnęli po sprzęt tak bliski im na co dzień jak komórka. I faktycznie, komórka okazuje się użyteczna także w tej sytuacji. Ankietowana gimnazjalistka tak opisuje sposoby radzenia sobie podczas sprawdzianu: $U$ nas nie byto sprawdzianu, żeby nie byto ściagi $w$ telefonie u kogokolwiek. 
[...] Na przyktad z matematyki byto jakieś zadanie, którego pani po prostu nie przewidywała, że taki dziwny wynik wyjdzie aż... no to wtaśnie jedna dziewczyna po prostu zapytała się, czy można skorzystać z kalkulatora ostatecznie, no i pani powiedziała: no to dobrze skorzystaj już. I ona po prostu ściage otworzyła [K 15].

Niekiedy nawet gdy pedagodzy podejmują pewne próby przeciwdziałania takim zachowaniom, nie sprzyja temu brak wiedzy na temat nowych technologii. Interesujący przypadek przywołano w prasie (Kołodziejczyk 2006, s. 12): „Piotr Rabiej z Twojej Komórki pamięta list od pewnego ucznia, który z radością donosił, że za pomocą komórkowej technologii bluetooth (szybka transmisja danych) jego klasa ściąga na klasówkach i wirtualnie podnosi swój poziom w oczach nauczycieli. Ciało pedagogiczne, dumne $z$ braku zasięgu sieci telefonicznych w szkole, zezwalało na korzystanie z komórek ze względu na zamontowane $\mathrm{w}$ nich kalkulatory. O bluetooth ciało nie miało pojęcia - widocznie nie zapuściło się w lekturze instrukcji obsługi własnych telefonów aż tak daleko". Wygląda na to, że w odwiecznej grze o autorytet i dyscyplinę komórka została skuteczniej wykorzystana przez uczniów.

Dzwonek telefonu w innych miejscach „oficjalnych”, sformalizowanych, obecnie jest powszechnie uznawany za nietakt, spotyka się z wyrazami dezaprobaty: wymowne spojrzenia, uwagi na temat kultury osobistej, a czasem nawet otwarte słowa krytyki — to sposoby na przywrócenie zakłóconej powagi miejsca.

Bardzo często rozmaite instytucje umieszczają w widocznych miejscach znaki zakazu korzystania z komórki, które przypominają o nieformalnych „zasadach kultury". Ważniejsze wydarzenia publiczne, spotkania, koncerty odczyty zwykle zaczynają się prośbą o wyłączenie telefonów. Mimo to miejsca, w których od rozmów telefonicznych należy się powstrzymać, podczas wywiadów często klasyfikowano ad hoc, większość respondentów potrzebowała chwili namysłu, często podawali miejsca związane z ich osobistymi doświadczeniami, jak ta rozmówczyni: Nie wiem... na jakichś imprezach okolicznościowych, $w$ kościele...i do lekarza nie powinien być używany. Miatam fatalna sytuacje, bytam u lekarza $i$ ciagle ktoś dzwonit... Boże... zamykałam torebkę, żeby nie byto stychać [śmiech] [K 53].

Nie oznacza to jednak, że respondenci stosują się do norm bezwzględnie, czy że nie relatywizują sytuacji: ...no, czasami sa sytuacje, że zostaje ktoś $w$ domu $i$ mam telefon może pilny, może coś się wydarzyto, to tak trudno ocenić, $w$ miejscach publicznych uważam, że nie. W teatrze, $w$ kinie, no $w$ kościele, nie powinno się używać, ale to zależy od sytuacji, jaka każdy ma [K 48]. Podobnie, choć mniej restrykcyjnie, postrzegane są przestrzenie półprywatne, na przykład sklep, urząd, poczta, gdzie bezpośrednia rozmowa jest uznawana za dopuszczalną, a rozmowa za pośrednictwem telefonu wciąż jest traktowana jako niewłaściwa i znacznie bardziej rozpraszająca niż „rzeczywista” konwersacja.

Przyczyna, dla której rozmowy przez komórkę w miejscach publicznych są tak irytujące, jest trudno uchwytna i w zasadzie zależna od cech indywidual- 
nych. Wydaje się jednak, że u źródeł leży intruzyjność tego narzędzia. Chyba najtrafniej ujął to dwunastolatek: wkurza mnie to,... no... nie można porozmawiać, bo zagłusza $i$ harmonię... [...] znaczy się tak... tak rażaco się wyróżnia [M 12_2]. Komórka powoduje zakłócenie nie tylko osobistych rozmów, ale też wkracza w przestrzeń publiczną. Rozmowa, z której słyszalny jest tylko fragment, powoduje, że rozmówca przenosi się gdzie indziej, tylko w części poświęcając uwagę miejscu, w którym przebywa. Stąd pojawiający się w wielu wypowiedziach wątek poczucia odtrącenia czy bycia lekceważonym. Komórka wkracza w przestrzeń zarezerwowaną dla spotkań fizycznych, sąsiedzkich pogaduszek, co zakłóca utarty zwyczaj i jest szczególnie rażące dla osób starszych, dla których przestrzeń publiczna - to przestrzeń bezpośrednich spotkań z ludźmi, telefon zaś - to sprawa prywatna. Często dopuszczalność konwersacji przez komórkę zależy od jej treści. W większości akceptuje się załatwienie spraw pilnych, zdecydowanie potępia zaś rozmowę na tematy osobiste w sklepie, urzędzie czy autobusie. W wielu wypowiedziach na temat postulowanych zasad respondenci w ocenie zdawali się na kulturę i takt rozmawiających przez telefon. Jeden $z$ respondentów rozmowy w miejscach użyteczności publicznej uznaje za uciążliwą konieczność naszych czasów i bardziej niż na przepisy i zakazy liczy na kulturę osobistą: $W$ miejscach publicznych to różne rzeczy się dzieja, wedtug mnie używanie telefonu jest najmniejszym nieszczęściem [M 55]. Jednoznacznie też deklaruje, że mimo uciążliwości nie odważyłby się zgłosić sprzeciwu.

U niektórych słuchanie o osobistych sprawach współpasażera czy towarzysza w kolejce budzi zażenowanie i zakłopotanie, wskazują to jako jeden $z$ powodów potencjalnej zasady nierozmawiania $\mathrm{w}$ miejscach publicznych: To jest takie trochę kręujace, bo stucha się czyichś osobistych spraw, a w zasadzie nie powinno się ich styszeć, bo to sa czyjeś sprawy i on nie mówi nam o tym, tylko rozmawia $z$ kimś innym [...] ale zazwyczaj staram się nie stuchać takich rozmów, nie zwracać uwagi na nie [K 14].

Jednocześnie część respondentów deklaruje, że obecność potencjalnych niepożądanych słuchaczy krępuje ich i skłania do ograniczenia tematyki rozmów lub rozmów w ogóle: Przeważnie $w$ autobusie rozmawiam na bardziej btahe tematy, wtaśnie staram się nie poruszać bardziej osobistych spraw, a nie dość że rozmawiam na błahe tematy, to staram się to robić dosyć dyskretnie, nie mówię, że szepczac, bo wiadomo, że to nie jest możliwe, ale staram się odwrócić, nieco przyttumić, zasłonić dtonia mikrofon, żeby wszyscy naokoło nie musieli styszeć wszystkiego, co ja mówię, nawet jak mówię o tym, że mam kupić chleb czy wędlinę, niekoniecznie musza to styszeć wszyscy naokoto, że idę na zakupy [K 24_2].

Jak widać, jako recepta na dyskomfort nieustannego bycia słyszanym i uczestnictwa $\mathrm{w}$ kilku przestrzeniach jednocześnie wybierane są powstrzymanie się od rozmowy na tematy istotne oraz próba wycofania się z przestrzeni publicznej na tyle, na ile to możliwe, chociażby symbolicznie.

Oczywiście, są osoby, którym rozmowy przez telefon komórkowy nie przeszkadzają, większość jednak podchodzi do tej kwestii z rezygnacją, na co wska- 
zują nie tylko poniższe wypowiedzi, ale postawy zauważalne na co dzień w biurach, sklepach i autobusach: Ale generalnie jeżeli chodzi tam o jakieś pociagi, tramwaje, to po prostu przecież nikt nikomu nie zabroni, jak jest taka potrzeba, żeby ten telefon wykonać, to raczej nie powinno być jakichś zakazów większych chyba [M 19]. Mnie się osobiście to nie podoba, aczkolwiek pewnie mnie też się to zdarza. ... Wolatabym nie styszeć, spraw prywatnych... [...] [K 37].

Jeszcze bardziej niejednoznaczne zasady są odnoszone do sytuacji, w której dzwonek telefonu czy sygnał SMS-a przerwie prywatną rozmowę osób o równym statusie (w rozmowach $\mathrm{z}$ osobami o wyższej pozycji w większości wypadków za oczywiste uznaje się zwykle zignorowanie rozmowy telefonicznej). $Z$ wypowiedzi respondentów wyłaniają się trzy możliwe wzory zachowań:

— odebrać, jeżeli jest to telefon ważny, krótko załatwić sprawę, a jeśli sprawa może zaczekać — zakończyć szybko rozmowę;

— odebrać i ewentualnie później wtajemniczyć w jej elementy współobecnych;

— zignorować telefon.

Reakcje na dzwonek u rozmówcy też mogą być różne: ... zachwycony pewnie bym nie byt, no ale cóż... no, trzeba to tolerować... trzeba to tolerować po prostu. [...] Normy wspótżycia... no bo o coś takiego się denerwować nie ma sensu... nie ma sensu... [M 65]; No to rozmawiatbym $z$ innymi... nie no, potem dokończylibyśmy rozmowe, mnie to tam... nie przeszkadza mi to [M 13]; To jest to takie krępujace bo osoba tak jakby bez stowa odkręca się na pięcie, idzie, kontynuuje rozmowe przez telefon, a nie wiadomo, jak się zachować, czy odejść, prawda, czy zostawić tę osobę, czy czekać... zaczekać, nie wiadomo, jak dtugo ta rozmowa będzie trwała [K 48].

Jeśli odrzuci się rozmowę, to przyjęte jest jako wręcz oczywiste, że należy oddzwonić, gdy tylko stanie się to możliwe. Ponieważ numer dzwoniącego jest znany, nietaktem jest pozostawić nieodebrany telefon bez odpowiedzi: Dzisiaj telefon nawet odłaczony żyje, nawet jak ktoś nie odbiera raz czy drugi, to przecież widać kto dzwoni... no i wypada oddzwonić, zwłaszcza ze znanego [M 55].

Osobna kwestia to odbieranie i wysyłanie SMS-ów. Wiadomości tekstowe, traktowane jako bardziej dyskretne, są tolerowane w przestrzeni publicznej. Często w miejscach, w których rozmowa jest źle widziana, istnieje społeczne przyzwolenie na esemesowanie, na przykład w kinie, w muzeum, w urzędzie. Wiadomość budzi ciekawość, a co za tym idzie, pokusę natychmiastowego odebrania, której trudno się oprzeć. Krótkie wiadomości tekstowe cieszą się przy tym ogromną popularnością ze względu na swą asynchroniczność. Odbieranie SMS-ów budzi mieszane uczucia, zwłaszcza w trakcie rozmowy z kimś. Część respondentów uważa to za nieeleganckie lub lekceważące, przejaw braku kultury, a według innych odbiór SMS-a jest dopuszczalny jako forma komunikacji dyskretna i nie angażująca: Nie, SMS akurat to inna sprawa, to nie przeszkadza $w$ rozmowie, to sie raz spojrzy, przeczyta i się kontynuuje rozmowe [M 19]. Opinie nie zależą tu od wieku. Pisanie SMS-ów natomiast, jako wymagające większej uwagi, nie jest akceptowane, co może wynikać $z$ tego, że piszący nie ma 
kontaktu wzrokowego z rzeczywistym rozmówcą, powstaje więc wrażenie nieobecności, ignorowania. Ponadto prowadzenie jednocześnie dwóch, zazwyczaj rozbieżnych, wątków wypowiedzi jest trudne do koordynacji, udaje się nielicznym, czego chyba niemal każdy miał okazję doświadczyć, podobnie jak ten respondent: No to też by trochę byto takie troche frustrujące...Generalnie to... widze po sobie, $w$ sytuacji jak pisze SMS-a i z kimś rozmawiam, nie, bo albo głupoty wysytam, albo gtupoty gadam koledze, $z$ którym rozmawiam. Generalnie staram się takich sytuacji unikać [M 19].

Opisane normy użycia komórki, powszechnie uznawane są za dopuszczalne, nie stanowią jednak kanonu, często ograniczają się tylko do grupy znajomych czy grupy rówieśniczej. Często zdarzają się niekonsekwencje w postawach danej osoby, która $z$ jednej strony deklaruje bardzo rygorystyczne podejście do używania komórek w miejscach publicznych, a $z$ drugiej — w toku wypowiedzi przytacza przykłady, które mogą sugerować, że w praktyce sama przekracza zasady przez siebie postulowane. Najczęściej preferowane jest, przynajmniej w sferze deklaracji, powstrzymanie się od rozmów osobistych i dbałość, by rozmowa $\mathrm{w}$ jak najmniejszym stopniu przeszkadzała otoczeniu.

\section{REKWIZYT W TEATRZE ŻYCIA CODZIENNEGO}

Telefon komórkowy wpisał się w codzienny krajobraz rzeczywistości, stał się wszechobecny, wciska się w niemal każde wydarzenie. Nawet wyłączony, wciąż zaprząta myśli - przypominają o nim tabliczki z zakazem rozmów czy uwagi, aby wyłączyć dźwięk. Komórka to częsty temat rozmów, narzekań, artykułów prasowych, „michałków” na zakończenie serwisów informacyjnych, pojawia się w filmach, kabaretach, reklamach i piosenkach - ten niepozorny przedmiot zyskał społeczne życie. Jak zauważa Karin Knorr-Cetina (1997), rozwój techniczny i procesy globalizacji, silnie powiązane z procesami indywidualizacji, powodują, że w miejsce dalszego wzrostu złożoności struktury społecznej coraz większego znaczenia nabierają relacje z obiektami. Obiekty wytwory systemów eksperckich - powszechnie stały się punktem odniesienia dla jednostek, tworzą konteksty autokonstrukcji, są elementami scalającymi tożsamość i pośredniczącymi w tworzeniu relacji międzyludzkich. Coraz częściej, twierdzi Knorr-Cetina, jednostki są socjalizowane do przedmiotów, a nie do wspólnoty, co jest o tyle istotne, że coraz częściej przedmioty zastępują w relacjach ludzi.

Teza o „socjalizacji do przedmiotów” wydaje się szczególnie trafna, jeśli weźmiemy pod uwagę adaptację komórek przez różne grupy wiekowe. Osoby starsze ewidentnie mają przy tym większe trudności, część czuje się zagubiona w obliczu nowej technologii, a nabycie komórki jest dla nich szokiem poznawczym. Nie chodzi tylko o konieczność nauki obsługi nowego urządzenia, komórka sprawia trudność przez wielość funkcji, jakie może pełnić, a także brak pewnych społecznych nawyków. Osoby, które w młodości spotkały się z tym 
wynalazkiem, łatwiej przystosowały się do tego, że wyciągnięcie telefonu, by zadzwonić do osoby, o której się właśnie pomyślało, jest normą. Zapewne jeszcze swobodniej przenośny telefon będą taktować dzieci, które są dosłownie „socjalizowane do komórki”, które dostają komórki-zabawki, a coraz częściej prawdziwe telefony. Jest to więc dla nich sprzęt $z$ najbliższego otoczenia od najmłodszych lat — „odkąd pamiętają”. Umiejętność obsługi komórki staje się obecnie oczywista.

Niezbędność przenośnego telefonu wynika po części z jego wielofunkcyjności - może on służyć jako zegar, budzik, terminarz-przypominacz, notatnik, kalkulator, gra, odtwarzacz muzyki, radio, aparat fotograficzny, dyktafon, kamera, telewizor, komunikator Gadu-Gadu, internet. Jednak większość użytkowników korzysta tylko z wybranych funkcji. Najczęściej z używaniem dodatkowych funkcji eksperymentuje młodzież, starsi korzystają raczej z podstawowych opcji przenośnego telefonu, czyli rozmowy i SMS, czasem przez badanych wymieniany był też zegarek, budzik, kalkulator, aparat fotograficzny. Nie jest to jednak reguła, wiele $\mathrm{w}$ tej kwestii zależy nie od wieku, lecz od indywidualnych zainteresowań. Z pewnością zaś, jak zauważył Marcin Kołodziejczyk (2006, s. 12), większość użytkowników ma dostęp do funkcji, „do których nigdy nawet nie dotrą, mimo że innych modeli już się nie produkuje".

Spośród dwudziestu ośmiu ankietowanych na potrzeby tej pracy tylko dwie osoby, poniżej dwudziestego piątego roku życia, były na bieżąco zorientowane we wszystkich technicznych możliwościach przenośnych telefonów i z nich rzeczywiście korzystały, dbały też, by systematycznie unowocześniać swój sprzęt. Młodzi ludzie w większości interesowali się nowinkami technicznymi, jednak nie przekładało się to na jakość posiadanego sprzętu. Możliwe, że brak własnych środków finansowych uzależnia zakup nowego telefonu od hojności rodziców. Dorośli powyżej czterdziestego roku życia mieli wiedzę o skomplikowanych funkcjach komórki, ale $z$ nich nie korzystali (lub tylko z pomoca dzieci). Wśród wykorzystywanych zastosowań wymieniali tylko te najbardziej podstawowe, a przy wyborze aparatu telefonicznego za najważniejszą uważali nie liczbę dodatkowych funkcji, ale łatwość obsługi, duży ekran i wygodną klawiaturę.

Inny aspekt „socjalizacji do komórki” polega na tym, że telefon komórkowy jest przedmiotem osobistym, do którego trzeba się przyzwyczaić, dopasować swoje nawyki, który jednocześnie staje się przedmiotem wielu zabiegów mających niejako „oswoić” aparat. Czynią tak zwłaszcza młodzi użytkownicy - przez dodanie breloczka czy smyczy, ustawienie tapety, która będzie pasowała [K 15] do właściciela, wybór stosownych dzwonków, zmianę obudowy itp. Komórka, nieustannie oglądana, dotykana, staje się częścią ubioru, czasem nawet luksusową, nierozerwalnie związaną z właścicielem, prawa ręka [K 24_2], która służy zarządzaniu osobistymi kontaktami. Nawet jeśli nie ma specjalnych ozdób i zabiegów „oswajających”, to bardzo często można zaobserwować emocjonalny stosunek do komórki, przejawiający się w określeniach: ten stary 
grat; taka cegietka, ale się do niej przyzwyczaitem; dobrze leży w dłoni, lubie go, czy stosowanych zdrobnieniach.

Należy dodać, że pytani starali się raczej nie eksponować przywiązania do tego sprzętu, czasem tylko w bardziej ogólnych wypowiedziach nastolatków owo emocjonalne przywiązanie niepostrzeżenie się pojawiało: Lubię mieć telefon, lubię być $w$ ogóle pod kontaktem... [K 14]. Możliwe, że niechęć do osobistych wypowiedzi, wynika z rezerwy w opowiadaniu obcemu o własnym życiu, może wydaje się to nieistotne „dla celów naukowych”, może otwartość taka traktowana byłaby jako nietaktowna wylewność... Nic w tym dziwnego, w końcu komórka towarzyszy posiadaczowi niemal cały czas, $\mathrm{w}$ drodze, $\mathrm{w}$ domu, w szkole, w pracy, nawet w nocy - leży przy łóżku i czuwa, by rano stać się budzikiem; towarzyszy trudnym, ważnym i radosnym wydarzeniom. To ona pośredniczy w ogromnej większości rozmów, o najróżniejszych, czasem bardzo osobistych sprawach, dlatego jej wygląd i „dopasowanie” do właściciela to nie tylko kwestia wygody, ale także nośnik rozmaitych wrażeń i stanów, o których znajomy kształt przedmiotu przypomina.

Wykształca się szereg charakterystycznych dla większości posiadaczy komórki zachowań, na przykład odruchowe zerkanie na ekran co jakiś czas, wyciągnięcie komórki po przyjściu w określone miejsce i położenie jej „na widoku", odruch sprawdzenia, czy jest w kieszeni lub torbie przed każdym wyjściem... Wypracowywane są systemy komunikacji, część wynika z oszczędności, na przykład nastolatki często „puszczają sygnał” (wybierają numer, bez zamiaru odbycia rozmowy, rozłączając się zanim telefon zostanie odebrany, tak że odbiorca słyszy dzwonek, a nadawca nie ponosi kosztów), na przykład jeśli chcą się skontaktować z rodzicami, gdy rozmowa nie jest potrzebna, by powiedzieć: „już jestem” (Castells i in. 2007, s. 66). Także w kręgu bliskich znajomych funkcjonuje zwyczaj, że jeśli ktoś nie ma pieniędzy na koncie, daje sygnał, aby oddzwoniono. Taki sposób komunikacji, obok SMS-ów, stosowany jest także, gdy dzwoniący nie jest pewny, czy odbiorca może rozmawiać: ...ja wtaściwie tylko do niej [córki] daje sygnat, jak coś się dzieje, bo to $w$ pracy to wiadomo... ona nie zawsze może po prostu rozmawiać, to ja jej sygnat daje $i$ ona za te 5-10 minut, kiedy tam będzie miata czas, to zawsze oddzwania [K 60].

Komórka jest też istotnym tematem konwersacji. Rozmowa zaczynająca się od słów: „Masz fajny telefon, czy dobrze się spisuje?”, zawsze jest wstępem do dłuższej pogawędki. Przenośny telefon wyzwala znaczne zaangażowanie, niezależnie od wieku rozmówców. Popularność tego tematu może wynikać z jego uniwersalności. Dotyczy przedmiotu oczywistego, o którym każdy ma coś do powiedzenia, choćby w formie narzekań. Jest przy tym mniej banalny niż pogoda i bezpieczniejszy niż polityka (potencjalne źródło sporów, prowadzące do kłótni i nieprzyjemnej atmosfery). Co więcej, istnieje niezliczona liczba anegdot i zabawnych sytuacji, które są przytaczane w trakcie rozmowy. Warto też zaznaczyć, że w rozmowach na tematy techniczne ustalił się nowy porządek hierarchii. Jeśli biorą $\mathrm{w}$ nich udział osoby $\mathrm{z}$ różnych grup wiekowych, to rolę 
ekspertów przejmują młodsi, a w towarzystwie zróżnicowanym płciowo prawie zawsze mężczyźni, którzy starają się wykazać większą wiedzą i oferują pomoc w rozwiązaniu problemów technicznych. Kobiety akceptują ten podział i zazwyczaj prośba o radę czy pomoc kierowana jest do osobników płci męskiej, nawet jeśli $\mathrm{w}$ pobliżu są inne kobiety. $Z$ jednej strony mamy więc do czynienia z odwróceniem porządku, swoistym dla naszej epoki, z drugiej strony, z jego ścisłym podtrzymaniem. $Z$ czego to może wynikać? Możliwe, że uporczywe przywiązanie do „męskich” i „kobiecych” ról w konwersacji wynika z tradycji — mężczyźni zwykle byli kształceni w kierunkach technicznych i wciąż są one postrzegane jako ich specjalność (na co wskazuje także różnica w liczbie studentów i studentek na politechnice). Możliwe też, że rola eksperta to tylko rodzaj autoprezentacji w konwersacji, obliczony na zrobienie wrażenia na rozmówczyniach, a kobiety podejmują tę grę, o czym pisał Robin Dunbar (1996), obserwując codzienne konwersacje (por. Fox 2007).

Przenośny telefon może pełnić także funkcje symboliczne. Wśród nastolatków jest wyznacznikiem „bycia w sieci”, w sytuacjach społecznych jego wyciągnięcie może podkreślać pozycję nie tylko towarzyską: jestem lubiany, ale i społeczną (Sulima 2007). „Właściciel publicznie demonstruje swoją decyzyjność i dyspozycyjność. Wysyła przekaz: jestem włączony w życie, przyłączony do wielu instytucji, jestem dobrze usytuowany" (Kołodziejczyk 2006, s. 7). Może też oznaczać wyłączenie się z przestrzeni, jasny sygnał, że dana osoba nie życzy sobie rozmowy. Kate Fox (2007, s. 127) przytacza następującą obserwację: „Zauważyłam także, że wiele kobiet, które przychodzą same do kawiarni i innych miejsc publicznych, używa dziś komórki jako «bariery», $\mathrm{w}$ zastępstwie tradycyjnej gazety czy czasopisma, żeby zasygnalizować swą niedostępność i zaznaczyć osobiste «terytorium». Komórka, nawet jeśli w danej chwili nie jest używana, położona na stole spełnia rolę skutecznego osobistego ochroniarza, zabezpieczenia przed niechcianym kontaktem towarzyskim".

Ruchomy telefon może być zastosowany jako nośnik znaczenia także $\mathrm{w}$ wielu innych sytuacjach, jest bowiem najłatwiej dostępnym rekwizytem w nieograniczonej liczbie spektakli rozgrywanych każdego dnia: może być pretekstem do rozpoczęcia lub zakończenia rozmowy, przychodzi z pomocą w sytuacjach niezręcznych, gdy nie wiadomo, jak się zachować, wypełnia czas jazdy autobusem czy stania $\mathrm{w}$ kolejce lub po prostu - czas: ...czasami jak już mi sie naprawdę nudzi, to zadzwonię do kogoś... tak żeby pogadać z nim, to też pewnego rodzaju sposób na zabicie tej nudy [M 24].

Jak wynika z powyższych przykładów, komórka to nie tylko pośrednik, element diady połączonej konkretnym celem, jakim jest porozumienie za pomocą telefonu bądź SMS-a. Jest też stroną relacji z osobistym przedmiotem, tak osobistym, że można się do niego „przywiązać”, mieć do niego emocjonalny stosunek. Wiele ankietowanych osób wciąż pamiętało nazwę modelu swojego pierwszego telefonu, nawet jeśli upłynęło już sporo czasu od jego wymiany. 


\section{CYFROWE KRÓLESTWO NASTOLATKÓW - ROLA TELEFONU KOMÓRKOWEGO W OKRESIE DOJRZEWANIA I BUDOWY TOŻSAMOŚCI}

Telefon komórkowy niespodziewanie — także dla jego twórców i operatorów sieci komórkowych - podbił serca nastolatków i stał się nieodłącznym elementem okresu dorastania. Obecnie niemal każdy młody człowiek ma własną komórkę. Niestety, trudno jest podać dokładne dane, ponieważ często są to nierejestrowane telefony na kartę lub na abonament wykupiony przez rodziców. W Europie w 2004 r. w przedziale wiekowym 15-25 lat 77,2\% osób posiadało telefon komórkowy (Castells i in. 2007, s. 129). Dziś prawdopodobnie odsetek ten zbliża się do poziomu nasycenia. Można przypuszczać, że podobna tendencja istnieje $\mathrm{w}$ Polsce: ankietowani gimnazjaliści stwierdzali, że zdecydowana większość $\mathrm{w}$ ich otoczeniu ma komórki (jeśli ktoś $\mathrm{w}$ klasie nie miał, to były to pojedyncze osoby, zwykle chłopcy); licealiści nie potrafili wymienić ani jednej osoby w swoim otoczeniu nie posiadającej własnego przenośnego telefonu.

Telefon komórkowy odgrywa istotną rolę w procesie dorastania, staje się przy tym elementem tożsamości, i to zarówno w warstwie materialnej, jak i psychologicznej. Jest nie tylko pośrednikiem w procesie autokonstrukcji, ale także narzędziem, wdraża do elastyczności w zarządzaniu czasem i kontaktami, spontaniczności, oswaja ze zmiennością otoczenia, tak swoistą dla współczesnych czasów, jednocześnie zapewniając poczucie bezpieczeństwa płynące $z$ „przebywania” w kręgu własnej grupy, słowem - wprowadza młodego człowieka we wszystkie dylematy życia w społeczeństwie ponowoczesnym.

Komórka także określa młodzieżowy styl życia, ułatwiając spontaniczne działania, które są tak charakterystyczne dla tego wieku. Nie ma już potrzeby spotykać się „przy trzepaku” czy „na rogu”, by ustalić, co robić w piątkowe popołudnie. W miejsce ścisłych ustaleń wchodzą luźne deklaracje, a szczegóły dopracowywuje się przez telefon, tak jak ilustruje to wypowiedź nastolatki: No to ci napiszę SMS-a albo zadzwonię [K 16_1], zostawiając sobie furtkę pozwalającą na zmianę planów, jeśli pojawi się bardziej interesująca perspektywa spędzenia popołudnia.

To nastolatki najczęściej wysyłają i odbierają SMS-y, co stało się podstawą takich roboczych określeń jak „pokolenie txt”, „plemię kciuka” (thumb tribe) (Castells i in. 2007, s. 14) czy „pokolenie SMS” (Sasińska-Klas 2003). Z przeprowadzonych wywiadów wynika jednak, że przypisywanie nastolatkom kultury SMS jako swoistej dla nich formy wypowiedzi nie w pełni opisuje rzeczywistość, starsze pokolenie bowiem jest dyskryminowane w korzystaniu z wiadomości tekstowych przez małe literki [K 60], a wraz z obniżeniem kosztów połączeń zmniejszyła się liczba SMS-ów wysyłanych przez młodzież. Jednak chociaż rozmowa jest wygodniejsza, szybsza i równie tania, SMS zachował swoją funkcję ekspresyjną jako środek podtrzymania więzi, podzielenia się informacją czy 
żartem, zwłaszcza gdy szybkość przekazu nie jest istotna lub rozmowa nie jest możliwa.

Kate Fox (2001, s. 15) wskazuje jeszcze jeden czynnik, który czyni SMS-y tak przydatnymi - pośredniość przekazu esemesowego pozwala wyrazić informacje trudne do przekazania wprost: „SMS-owanie pozwala nastolatkom (i niektórym dorosłym mężczyznom) przezwyciężyć niezręczność i zahamowania, i rozwinąć społeczne oraz komunikacyjne umiejętności — komunikują się z większą ilością osób i częściej niż przed pojawieniem się komórek".

Okres dorastania to czas eksperymentowania, także $z$ tożsamością, telefon komórkowy pozwala na przybieranie identyfikacji i równie szybką ich zmianę, jak zmiana dzwonka. Umożliwia operowanie rozmaitymi narracjami, z których łatwo się wycofać, gdy okażą się niewłaściwe, co jest szczególnie użyteczne w swoistym dla adolescencji procesie kreacji własnego Ja (Gergen 1994). Warunkiem ukształtowania satysfakcjonujących relacji jest bowiem umiejętność stosowania różnych narracji, dopasowanych do czynników zewnętrznych, zwłaszcza gdy wobec zaniku markerów pozycji relacje zdominowane są przez niepewność znaczeniową.

Przenośny telefon szybko podbił rynek młodzieżowy, ponieważ pozwala na korzystanie z niezależności, rodzice bowiem łatwiej godzą się na rozszerzenie obszaru wolności, gdy istnieje możliwość kontroli. Ta nieustanna dostępność może jednak nieść pewne zagrożenia: po pierwsze, świadomość nieustannego kontaktu z opiekunami może skutkować brakiem poczucia odpowiedzialności, skoro „W razie czego" rodzice są na wyciągnięcie ręki, by udzielić pomocy, $z$ drugiej strony, jak zauważa Sherry Turkle (2006, s. 13), nieustannie dzwoniąca komórka nie daje możliwości „bycia samemu ze sobą” i sformułowania jakiejkolwiek autorefleksji, gdyż ciągle ma się świadomość pozostawania w zasięgu wszystkich znajomych, którym bezrefleksyjnie komunikuje się swe stany emocjonalne. Jak widać, to co wedle jednych jest zaletą (możliwość łatwiejszego wyrażania uczuć przez osoby nieśmiałe i z większą rezerwą, jak twierdzi przywołana wyżej Kate Fox; 2001), inni postrzegają w zupełnie innym świetle.

Obecnie nastolatki są $\mathrm{w}$ fazie negocjacji $z$ dorosłymi reguł dotyczących komórki i obie strony na własną rękę starają się jakoś uporać z intruzem, bez którego jednak wszystkim trudno wyobrazić sobie codzienne funkcjonowanie. Wydaje się, że tajemnica sukcesu telefonu komórkowego wśród tej grupy wiekowej polega na jego wielofunkcyjności i idealnym dopasowaniu do potrzeb okresu dojrzewania - jest narzędziem emancypacji, a jednocześnie zapewnia pewien stopień nadzoru, jest przedmiotem osobistym, dając się przy tym dowolnie kształtować wedle upodobań i potrzeb. Nigdy się nie nudzi, wciąż jest bowiem wzbogacany o nowe funkcje, zaspokajając młodzieńczą potrzebę wrażeń, a co najważniejsze - wdraża do elastyczności, kreatywności i zarządzania informacjami, które są przecież głównym zasobem społeczeństwa ponowoczesnego. 


\section{REWOLUCJA CZY POWRÓT DO PRZESZŁOŚCI?}

Życie ludzkie składa się z działania, które zawsze przebiega w określonej przestrzeni i w otoczeniu przedmiotów stanowiących punkt odniesienia tego działania, a więc tworzących część wewnętrznie przyswojonego schematu. W codziennym połączeniu przedmiotów i działań kryje się pamięć i wiedza społeczna, które są przekazywane w postaci przyzwyczajenia (Kaufmann 2004, s. 167). Miejsce, jakie dany przedmiot zajmuje w społeczeństwie, jest wyznaczane przez użytkowników. Powstaje w ten sposób uniwersum znaczeń zgodne $z$ kodami danej kultury, a na tej podstawie jednostki tworzą własne mapy poznawcze, uzupełniając pamięć społeczną o kształtowane przez siebie nowe schematy. Otoczenie społeczne, w którym zanurzone są jednostki i przedmioty o nadanym im znaczeniu, wywiera wpływ zwrotny. Jednostka jest bowiem tworem społecznym, procesem nieustannie rozgrywającym się między ramami socjalizacji, indywidualną spuścizną przyzwyczajeń, refleksyjnością społeczną i refleksyjnością indywidualną (Kaufmann 2004).

Towarzyszący człowiekowi na co dzień przenośny telefon idealnie wpisuje się w skomplikowany proces autokreacji wymuszany na jednostce żyjącej w ponowczesności. Tempo przyswojenia komórki wynika z jej przystosowania do współczesnego społeczeństwa, z jego charakterystyczną płynnością i globalizacją przepływów. Uwikłany w codzienny taniec z przedmiotami mobilny telefon jest zarazem odpowiedzią na zmiany i ich generatorem.

Obserwacja zachowań związanych z telefonem komórkowym pozwala dostrzec, że wspólnoty i więzi, wbrew głosicielom kryzysu społeczeństwa, wcale nie zanikają, lecz zmieniają formę. Zwiększona mobilność, która sprawia, że w drugiej połowie XX wieku świat „skurczył się”, a także życie w dużych skupiskach powodują, że wspólnoty oparte na bliskości przestrzennej stały się niepraktyczne i niemożliwe, żyjemy wszak w metropoliach, które nie dają możliwości poznania wszystkich dookoła. Telefon komórkowy pozwala przezwyciężyć przestrzenne ograniczenia i umożliwia kontakt „na wyciągnięcie ręki” z bliskimi, którzy są oddaleni w przestrzeni.

Interakcje zapośredniczone przez telefon komórkowy przybierają kształt podobny do tego, jaki Linnda Caporael przypisała społecznościom zbieracko-łowieckim. Telefon komórkowy w zależności od sytuacji może stanowić element diady. Jest wówczas nieustannie dopasowywany do preferencji użytkownika (kształtem, kolorem, interfejsem, doborem funkcji), tak aby można było jak najsprawniej nawiązać kontakt $z$ drugą osobą. Może też pośredniczyć w koordynacji zadań wykonywanych przez kilka osób, na przykład w przypadku ustalania miejsca spotkania.

Jak wskazują badania, kontakt telefoniczny nie jest nawiązywany przypadkowo, częstotliwość interakcji podejmowanych za pomocą telefonu zależy od siły i rodzaju więzi łączącej rozmówców, przy czym występuje tu prawidłowość, że im silniejszy związek emocjonalny, tym częstszy wzajemny kon- 
takt. Grupa osób, z którymi kontakt jest stale podtrzymywany, to rodzina (dzieci/rodzice, brat/siostra, babcia/dziadek) i grono bliskich znajomych (przyjaciel/przyjaciółka, chłopak/dziewczyna, znajomi z pracy). Jak wynika z moich szacunków - to około pięciu-dziesięciu osób, czyli - wedle teorii Linndy Caporael — grupa zadaniowa, w której zachodzi socjalizacja i wymiana informacji niezbędna do wykonywania zadań. To brak kontaktu $z$ tą grupa, a więc brak możliwości wymiany i potwierdzenia wspólnej reprezentacji rzeczywistości jest najbardziej uciążliwy. Na poziomie wyższym — deme, czyli około trzydziestu osób wzajemnie się kontaktujących, niezwłoczność kontaktu nie jest tak niezbędna; tu kształtowane są prowizoryczne normy postępowania z komórką, sposoby komunikacji, wspólne skróty stosowane w SMS-ach, ponieważ komórka - wynalazek stosunkowo nowy — nie podlega jeszcze normom na tyle sztywnym, by swoiste były dla całego społeczeństwa.

Podążając za modelem Linndy Caporael i poszukując poziomu macrodeme - skupienia wspólnot lub ich reprezentantów, którzy podzielają pewną wizję świata i chcą ją ustanowić jako normę, warto zwrócić uwagę na zjawisko, które stało się możliwe wraz z upowszechnieniem komórek, czyli smartmobs improwizowanych zgromadzeń zwoływanych za pomocą telefonów komórkowych, by wspólnie wyrazić protest lub poparcie dla jakiejś idei. Spontaniczne zgrupowania złożone są wszak z osób, które podzielają jakiś światopogląd i nie tylko go manifestują, ale chcą także zmienić rzeczywistość tak, by była zgodna z tym światopoglądem - chcą na nowo uzgodnić zasady. Owe spontaniczne zgromadzenia nie stanowią sztywnej organizacji, stoją w opozycji do zhierarchizowanej władzy i powstają, gdy jacyś ludzie uznają, że jest konieczne, aby zaprotestować przeciw skostniałym formom reprezentacji, z którymi się nie identyfikują. Można więc powiedzieć, że gdy nowoczesna forma reprezentacji społecznej staje się nieefektywna, spontaniczne zgromadzenia przejmują jej funkcje jako konkurencyjna reprezentacja interesów, poglądów czy wartości i dążą do zmiany. Forma ta zajmuje miejsce rytuałów religijnych czy uroczystości państwowych charakterystycznych dla społeczeństw tradycyjnych i nowoczesnych. Zygmunt Bauman (2001) zjawisko gromadzenia się jednostek wokół obiektu, przedmiotu czy wydarzenia nazwał wspólnotą zawieszenia. Jedność odczuć pojawiająca się w tego rodzaju wspólnotach, według niego, jest krótkotrwała i doraźna, a one same istnieją dopóty, dopóki problem, wokół którego się skupiły, jest w stanie przykuć uwagę uczestników. Jednak wyjaśnienie to wydaje się niepełne, gdyż SMS wzywający do gromadzenia się jest przesłany przez kogoś znajomego, wiarygodnego, z którym odbiorcę łączy już więź na tyle silna, by apel o wsparcie był skuteczny. Spontaniczne zgromadzenia nie zawsze odnoszą sukces, trudno też sobie wyobrazić, że staną się trwałym rytuałem, ich istotę stanowi bowiem spontaniczność i krótkotrwałość. Cele takich mobilizacji mogą być różne, podobnie jak skutki. Castells w sukcesie mobilizacji ad hoc upatruje siłę realnych więzi podtrzymywanych tylko wirtualnie. Według niego, mechanizm smartmobs połączony jest $z$ efektem sieci. Idea roz- 
wija się w obrębie jakiejś sieci, następnie przepływa do innej sieci znajomych przez ich kanały kontaktów. W tej horyzontalnej masowej komunikacji między osobą a osobą upatruje się największą siłę tego rodzaju mobilizacji. Kontekst, w jakim funkcjonuje dana wiadomość (i jego zmienność, także będąca wynikiem nieustannego dopływu informacji na temat bieżących zdarzeń), zaangażowanie emocjonalne i wiara w powodzenie, odzew, jaki wiadomość uzyska, pochodzenie $z$ wiarygodnego źródła są kluczowymi elementami siły politycznej drzemiącej w smartmobs. Wydaje się, że bez względu na skutki znamienny jest sam fakt zaistnienia tego zjawiska — jednoczesne zaangażowanie dużej liczby jednostek, co wskazuje, że nowoczesny poziom macrodeme nie spełnia swoich funkcji w obliczu zachodzących współcześnie zmian i że istnieje potrzeba poszukiwania innych, nowych sposobów tworzenia uniwersum znaczeniowego.

Obserwując te nowe sposoby inicjowania interakcji można zauważyć, że podstawowe typy ich powtarzalnych skupień są stałe, zmienia się natomiast i podlega negocjacjom forma ich inicjowania i podtrzymywania. To, że współczesne wspólnoty nie są widoczne gołym okiem, wynika $z$ faktu, że zasadą ich organizacji nie jest wspólna przestrzeń, lecz wspólnota ideałów i doświadczeń. Nie można już postrzegać grupy jedynie w kategoriach sztywnej społeczności o pewnej lokalizacji, nawet narody w epoce powszechnej mobilności są coraz bardziej rozproszone $z$ powodu migracji. Komórka świetnie wpisuje się $\mathrm{w}$ potrzeby użytkowników, wspomaga bowiem uwspólnianie wiedzy w rozproszonych wspólnotach, ułatwia społeczne podejmowanie decyzji i umożliwia podtrzymywanie więzi z jej członkami, „łatając” pęknięcie indywidualizacyjne. Wydaje się, że tylko poziom macrodeme trwa jeszcze w swej nowoczesnej manifestacji, jaką jest państwo narodowe, narzucające pewne zachowania $\mathrm{w}$ formie prawa, lecz coraz mniej efektywnie. Na podstawie obserwacji młodzieży można przypuszczać, że wspólną, globalną przestrzenią uwspólniania wiedzy - w dodatku wiedzy dostępnej na każde zawołane — stanie się internet, zlokalizowany w przenośnym urządzeniu, które każdy ma przy sobie.

Nie nastąpi to prawdopodobnie $\mathrm{w}$ najbliższych latach, jednak tempo wzrostu liczby użytkowników telefonów komórkowych i internetu, obniżenie kosztów i ulepszenia technologii informacyjnych pozwalają przypuszczać, że bariery dostępu znikną. Wkrótce też powszechnie dostępna, także finansowo, będzie nowa generacja komórek, wyposażonych w telewizję, dostęp do internetu oraz komunikatorów internetowych — wtedy niemal każdy będzie w sieci. Postęp techniczny sprawia, że coraz łatwiejsze jest nawiązanie kontaktu $z$ innymi ludźmi, a to przecież podstawowy warunek wszelkich zmian społecznych.

Możliwości telefonu komórkowego wyznaczają potencjał nowej przestrzeni negocjacji norm i uwspólniania wiedzy. Czy ułatwi to wyjście z kryzysu i przyspieszy przejście do nowego typu organizacji społeczeństwa, trudno przesądzać, ponieważ - jak zauważają autorki analizy przemian form uspołecznienia Mirosława Marody i Anna Giza-Poleszczuk (2004, s. 342) — „Tak jak dla XVI- czy nawet XVII-wiecznych myślicieli nie do wyobrażenia był porządek 
społeczny bez monarchy, uświęconych tradycją odrębności klas społecznych, dominującej roli religii, tak nam trudno sobie wyobrazić, jak zmieni się struktura społeczna, w jaki sposób podejmowane będą decyzje dotyczące szerszych społeczności i przez odwołanie do jakich argumentów uzasadniać będą swoje działania jednostki. Można jedynie $z$ dużą dozą prawdopodobieństwa założyć, $\dot{z}$ e formy organizacji życia społecznego, jakie wyłonią się po zakończeniu okresu przejścia ponowoczesnego, będą całkowicie odmienne od tych, które uznajemy dziś za oczywiste".

\section{BIBLIOGRAFIA}

Arent Igor, 2007, Inwazji ciag dalszy, „Twoja Komórka”, nr 11/118.

Bauman Zygmunt, 2001, On Mass, Individuals, and Peg Communities, w: Nicolas Lee, Rolland Munro (red.), The Consumption of Mass, Wiley-Blackwell Publishers, Oxford-Malden, MA.

Bauman Zygmunt, 2003, Razem, osobno, tłum. Tomasz Kunz, Wydawnictwo Literackie, Kraków.

Beck Ulrich, 2002, Społeczeństwo ryzyka. W drodze do innej nowoczesności, tłum. Stanisław Cieśla, Scholar, Warszawa.

Bendyk Edwin, 2004, Nieprzewidywalny inteligentny thum, „Polityka”, nr 41.

Castells Manuel i in., 2007, Mobile Communication and Society: A Global Perspective, MIT Press, Cambridge, MA.

Cieślak Jacek, 2007, Co tak pięknie gra? Komórka, „Rzeczpospolita”, 7 marca, A 13.

Dunbar Robin, 1996, Grooming Gossip and the Evolution of Language, Harvard University Press, Cambridge, Mass.

Erikson Erik H., 1997, Dzieciństwo i społeczeństwo, tłum. Przemysław Hejmej, Rebis, Poznań.

Fox Kate, 2001, Evolution Alienation and Gossip: The Role of Mobile Telecommunications in the 21st Century, www.sirc.org/publik/gossip.shtml [01.02.2008].

Fox Kate, 2007, Przejrzeć Anglików. Ukryte zasady angielskiego zachowania, tłum. Agnieszka Andrzejewska, Muza, Warszawa.

Gergen Kenneth J., 1994, Realities and Relationships: Soundings in Social Construction, Harvard University Press, Cambridge, Mass.

Giddens Anthony, 2001, Nowoczesność $i$ tożsamość. „Ja” $i$ spoleczeństwo w epoce późnej nowoczesności, tłum. Alina Szulżycka, Wydawnictwo Naukowe PWN, Warszawa.

Kaufmann Jean-Claude, 2004, Ego. Socjologia jednostki. Inna wizja człowieka i konstrukcji podmiotu, tłum. Krzysztof Wakar, Oficyna Naukowa, Warszawa.

Knorr Cetina Karin, 1997, Sociality with Objects: Social Relations in Postsocial Knowledge Societies, „Theory, Culture and Society”, t. 14, s. 1-29.

Kołodziejczyk Marcin, 2006, Organizm wielokomórkowy, „Polityka”, nr 17/18.

Levison Paul, 2006a, Miękkie ostrze, czyli historia i przysztość rewolucji informacyjnej, tłum. Hanna Jankowska, Muza, Warszawa.

Levison Paul, 2006b, Telefon komórkowy. Jak zmienit świat najbardziej mobilny ze środków komunikacji, tłum. Hanna Jankowska, Muza, Warszawa.

Ling Rich, 2004, The Mobile Connection: The Cell's Phone Impact on Society, Morgan Kaufman Publishers, San Francisco. 
McLuhan Marshal, 2004, Zrozumieć media. Przedtużenia człowieka, tłum. Natalia Szczucka, Wydawnictwa Naukowo-Techniczne, Warszawa.

Marody Mirosława, Giza-Poleszczuk Anna, 2004, Przemiany więzi społecznych, Scholar, Warszawa.

Postman Neil, 2004, Technopol. Triumf techniki nad kultura, tłum. Anna Tanalska-Dulęba, Muza, Warszawa.

Raport, 2007, Raport o stanie rynku za rok 2006, Urząd Komunikacji Elektronicznej, Warszawa.

Riesman David, 1996, Samotny tłum, tłum. Jan Strzelecki, Muza, Warszawa.

Sasińska-Klas Teresa, 2003, Pokolenie SMS-u w Polsce w świetle badan porównawczych, „Studia Medioznawcze", nr 5.

Stankiewicz Piotr, 2007, Konflikty technologiczne $w$ społeczeństwie ryzyka. Przykład sporu o budowę masztu telefonii komórkowej, „Studia Socjologiczne”, nr 4.

Sulima Roch, 2007, Telefon komórkowy - busola codzienności, w: Wiesław Godzic, Maciej Żakowski (red.), Gadżety popkultury. Społeczne życie przedmiotów, Wydawnictwa Akademickie i Profesjonalne, Warszawa.

Turkle Sherry, 2006, Always-on/Always-on-you: Tethered Self, w: James Katz (red.), Handbook of Mobile Communication and Social Change, MIT Press, Cambridge, MA.

\section{THE MOBILE PHONE - TOOL OF COMMUNICATION, TOOL OF SOCIAL CHANGE}

\section{Summary}

The mobile telephone is an invention which has extremely quickly become an integral part of everyday life and has definitively changed the habits of individuals. It became an obvious context of interaction and the observation of the methods of its use in different social groups allow the following of the process of the formation of new patterns of behaviour and social norms which have been created around this tool. The topic of discussion is in what manner the contacts maintained by the mobile telephone has influenced the shaping of social relations and the maintenance of social bonds in the conditions observed by theoreticians of the social process of individualisation. The possibilities of overcoming the spatial limitations which the mobile phone creates and above all the multiplicity of its functions and uses mean that it has a powerful potential for creating change.

\section{Key words/słowa kluczowe}

individualisation / indywidualizacja; socialisation / socjalizacja; social relations / relacje społeczne; social norms / normy społeczne; bonds / więzi; dyad / diada; deme / deme; macrodeme / makrodeme; task force / zespół zadaniowy; socialised object / przedmiot uspołeczniony 